\title{
Characterisation of the Convective Hot-Air Drying and Vacuum Microwave Drying of Cassia alata: Antioxidant Activity, Essential Oil Volatile Composition and Quality Studies
}

\author{
Lisa Yen Wen Chua ${ }^{1}$, Bee Lin Chua ${ }^{1, *}{ }^{\oplus}$, Adam Figiel ${ }^{2}{ }^{\oplus}$, Chien Hwa Chong ${ }^{3}{ }^{\oplus}$, \\ Aneta Wojdyło ${ }^{4}{ }^{(}$, Antoni Szumny ${ }^{5}\left(\mathbb{D}\right.$ and Krzysztof Lech ${ }^{2}$ \\ 1 School of Engineering, Taylor's University, Lakeside Campus, No. 1, Jalan Taylor's, Subang Jaya, \\ Selangor 47500, Malaysia; lisacyw92@gmail.com \\ 2 Institute of Agricultural Engineering, Wrocław University of Environmental and Life Sciences, 37a \\ Chełmońskiego Street, 51-630 Wrocław, Poland; adam.figiel@upwr.edu.pl (A.F.); \\ krzysztof.lech@upwr.edu.pl (K.L.) \\ 3 School of Engineering and Physical Sciences, Heriot-Watt University Malaysia, No. 1 Jalan Venna P5/2 \\ Precinct 5, Putrajaya 62200, Malaysia; chien_hwa.chong@hw.ac.uk \\ 4 Department of Fruit, Vegetable and Plant Nutraceutical Technology, Wrocław University of Environmental \\ and Life Sciences, 37 Chełmońskiego Street, 51-630 Wrocław, Poland; aneta.wojdylo@upwr.edu.pl \\ 5 Department of Chemistry, Wrocław University of Environmental and Life Sciences, Norwida 25, \\ 53-375 Wrocław, Poland; antoni.szumny@upwr.edu.pl \\ * Correspondence: beelin.chua@taylors.edu.my; Tel.: +601-73-099-682
}

Received: 1 April 2019; Accepted: 22 April 2019; Published: 24 April 2019

\begin{abstract}
The preservation of active constituents in Cassia alata through the removal of moisture is crucial in producing a final product with high antioxidant activity. This study aims to determine the influences of various drying methods and drying conditions on the antioxidant activity, volatiles and phytosterols content of $C$. alata. The drying methods used were convective drying $(\mathrm{CD})$ at $40^{\circ} \mathrm{C}$, $50^{\circ} \mathrm{C}$ and $60^{\circ} \mathrm{C}$; freeze drying; vacuum microwave drying (VMD) at 6, 9 and $12 \mathrm{~W} / \mathrm{g}$; and two-stage convective pre-drying followed by vacuum microwave finish drying (CPD-VMFD) at $50{ }^{\circ} \mathrm{C}$ and $9 \mathrm{~W} / \mathrm{g}$. The drying kinetics of $C$. alata are best described by the thin-layer model (modified Page model). The highest antioxidant activity, TPC and volatile concentration were achieved with CD at $40^{\circ} \mathrm{C}$. GC-MS analysis identified the presence of 51 volatiles, which were mostly present in all samples but with quantitative variation. The dominant volatiles in fresh C. alata are 2-hexenal $(60.28 \mathrm{mg}$

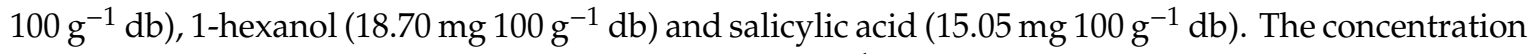
of phytosterols in fresh sample was $3647.48 \mathrm{mg} 100 \mathrm{~g} \mathrm{~g}^{-1} \mathrm{db}$, and the major phytosterols present in fresh and dried samples were $\beta$-sitosterol (1162.24 mg $100 \mathrm{~g}^{-1} \mathrm{db}$ ). CPD-VMFD was effective in ensuring the preservation of higher phytosterol content in comparison with $\mathrm{CD}$ at $50^{\circ} \mathrm{C}$. The final recommendation of a suitable drying method to dehydrate $C$. alata leaves is $\mathrm{CD}$ at $40^{\circ} \mathrm{C}$.
\end{abstract}

Keywords: Cassia alata; vacuum microwave; antioxidant activity; essential oil volatile composition; phytosterol; drying technology

\section{Introduction}

The majority of the world population has used medicinal plants in some ways as their first source of treatment as remedy for infectious and non-infectious diseases. Many of these medicinal plants have been researched and have garnered scientific evidence to be considered and used in general medical practice. A large number of diseases are caused by oxidative stress that can elicit cellular and 
tissue damage-a result of increased levels of free radicals or reactive oxygen species (ROS). Deficiency of antioxidants or overproduction of ROS in the body can cause the disturbance in the equilibrium between ROS formation and elimination, favouring the upsurge of ROS, which results in oxidative stress [1]. Hence, discovering plants that exhibit antioxidant effect that can be a potential source of antioxidants is necessary.

Cassia alata (Leguminosae) is a shrub native to Southeast Asia, Northern Australia, Latin America, Fiji and Africa and can be found widespread in tropical regions, cultivated for medicinal purposes [2,3]. C. alata is known as gelenggang in Malaysia, ringworm bush in Australia, mbai ni thangi in Fiji and te'elango in Tango [2]. This shrub can grow up to $3 \mathrm{~m}$ in height. The leaves are 30-40 cm long, pinnately compound, have 6-12 pairs of broad leaflets, blunt at the tip portion, with unequal base and are $15 \mathrm{~cm}$ long and $8 \mathrm{~cm}$ wide. The flowers are golden yellow, roundish in axillary racemes that are $3-4 \mathrm{~cm}$ wide and 20-30 cm long [4]. C. alata is widely used in folk medicine and home remedies for treating common ailments, such as ring worm, skin diseases, rheumatism, diabetes, stomach pain, constipation and gonorrhoea $[3,5]$. Numerous past reports on the promising antioxidant effect shown by C. alata extract have prompted the investigation of the influence of drying methods on the antioxidant activity and chemical constituents [6-8]. The leaf extract of C. alata is reported to contain phenols, flavonoids and anthraquinones, which is believed to contribute to the strong antioxidant effect of the plant extract [6].

Freshly harvested medicinal plants have high water content and are thus categorised as perishable commodities. Unfavourable enzymatic and metabolic activities are likely to occur due to high water content, in addition to the increased susceptibility to microbial growth [9]. Bioactive content may reduce considerably in the raw material between the period of harvesting and processing. Effective preservation via the removal of moisture is needed to inactivate enzymatic degradation and chemical and metabolic reactions [10]. Drying operations have been used in the food processing industry for the preservation of final product. The primary aim of drying is to reduce moisture in food to a level that can avoid microbial spoilage. However, drying can also be seen as a process that retains important constituents in raw herbs with nutraceutical properties [11].

Convective drying (CD) remains the most widely used drying method for reducing moisture from fruits, vegetables and medicinal plants. However, CD methods have several limitations; for example, they are a low energy efficiency drying method and may not necessarily produce dried medicinal herbs with high retention of bioactive compounds [9]. In addition, CD is a surface heating method. Firstly, water evaporates from the surface of food material, and the subsequent moisture removal from the inner regions of raw material is driven by a moisture concentration gradient. Diffusion of moisture from the centre areas of the material to the surface is slow and rate limiting, thereby resulting in low drying rate at the final stage of drying [12]. Prolonged drying durations can result in extensive quality deterioration in the final dried product [13]. At the same time, bioactive constituent loss may also be contributed by the long exposure of plants to oxygen during the CD process [14].

The introduction and application of hybrid drying technologies are necessary to overcome the limitations of conventional drying methods whilst considering the sensitivity of bioactive constituents in medicinal herbs to thermal degradation and oxidation. Combined drying methods are perceived as more versatile because the advantages of two or more drying methods may offer better drying outcomes than an individual approach [9]. Vacuum microwave drying (VMD) is a combined microwave heating and vacuum drying method. This combination is deemed appropriate for drying process to occur in a reduced pressure environment, thereby lowering oxidation reactions and lowering the boiling point of water. During the process of VMD, microwaves will penetrate the plant material and cause water to be heated up via dipole rotation and ionic conduction, thereby causing water vaporisation at a low temperature under a reduced pressure condition [11]. In addition to increasing the drying rate with VMD's volumetric heating, the lower pressures used can induce rapid water evaporation from plant materials at a low drying temperature, thereby minimising possible chemical alterations in plant material by high temperatures [15]. 
The problem with VMD is that high water evaporation from the plant material at the initial stage of drying may exceed the vacuum pump's capacity; therefore, the material load has to be reduced, or a large vacuum pump installation is often required $[11,16]$. Installing a large-scale vacuum pump requires a large capital and can potentially incur a large processing cost. Convective pre-drying followed by vacuum microwave finish drying (CPD-VMFD) is a two-stage combined drying method in which the raw material is pre-dried using CD and finish dried with VMD. This method has been used in numerous studies being a cheaper alternative of VMD in terms of capital expenditures and operating costs. The high retention of bioactive constituents in various biomaterials has also been reported with this two-stage method [17].

The present study aims to evaluate the influences of various drying methods, conventional drying method, CD, new drying technologies (namely, VMD and CPD-VMFD) and the respective drying intensities on the total phenolic content, antioxidant activity, volatiles and phytosterol content. The fatty acid profile of the plants was ascertained to understand the active constituents contained in C. alata. The drying kinetics was modelled with three common thin-layer drying models to integrate the experimentally acquired data into industrial applications, thereby providing the basis for the understanding of the unique drying characteristics of $C$. alata. Drying is considered the most energy-intensive operation in the food industry. Thus, this study also determined the relationship of the drying kinetics of $C$. alata with the corresponding energy input of a drying operation. The specific energy consumptions were used to provide an estimate of the cost-effectiveness of the drying of C. alata, which has yet to be reported. Colour properties and water activities of fresh and dried samples, which serve as quality indicators, were also determined.

\section{Results and Discussion}

\subsection{Drying Kinetics}

Figure 1a shows the change of moisture ratio (MR) with time, Figure $1 \mathrm{~b}$ shows the relationship between the drying rate and MR and Figure $1 \mathrm{c}$ shows the change of moisture content with time of C. alata dried using $\mathrm{CD}$ at $40^{\circ} \mathrm{C}, 50^{\circ} \mathrm{C}$ and $60^{\circ} \mathrm{C}$, VMD at $6 \mathrm{~W} / \mathrm{g}, 9 \mathrm{~W} / \mathrm{g}$ and $12 \mathrm{~W} / \mathrm{g}$ and CPD-VMFD at $50^{\circ} \mathrm{C}$ and $9 \mathrm{~W} / \mathrm{g}$. As shown in Figure $1 \mathrm{a}, \mathrm{c}$, the drying duration of $\mathrm{CD}$ is the longest as convective method uses surface heating, and surface moisture is removed efficiently; however, the slow diffusion of moisture from the internal region is rate limiting. A rapid moisture removal in the initial stage of $\mathrm{CD}$ is typical, and moisture removal will progressively reduce with time. With $\mathrm{VMD}$, the volumetric heating of microwaves addresses the limitation of $C D$ because the water removal from the centre region is fast, thereby resulting in higher drying rates than $C D$ methods. A higher drying rate during the initial period of VMD is often observed as a larger microwave radiation is absorbed due to a higher moisture level in leaves. As drying progresses, lower moisture content in leaves corresponds to the lower microwave absorption, thereby lowering the drying rate. In the combined method CPD-VMFD, CPD is effective in removing moisture during the initial drying process whilst VMFD assists in the removal of residual moisture, which is strongly bound to the plant cellular structure, thereby shortening CD from $150 \mathrm{~min}$ to $105 \mathrm{~min}$.

With regard to $\mathrm{CD}$ and $\mathrm{VMD}$, high drying intensities resulted in reduced drying durations and high drying rates. Increasing hot-air temperature for $\mathrm{CD}$ from $40^{\circ} \mathrm{C}$ to $60^{\circ} \mathrm{C}$ reduced drying time from $180 \mathrm{~min}$ to $120 \mathrm{~min}$. Meanwhile, for VMD, increasing microwave wattage from $6 \mathrm{~W} / \mathrm{g}$ to $12 \mathrm{~W} / \mathrm{g}$ reduced drying time from $32 \mathrm{~min}$ to $16 \mathrm{~min}$. The trend of MR with time of CD and VMD at different drying intensities is similar (Figure 1a). Drying kinetics of $C$. alata dried using CD, VMD and CPD-VMFD are best described by an exponential function (modified Page model).

$$
M R=a \cdot \exp \left(-k \cdot t^{n}\right)
$$




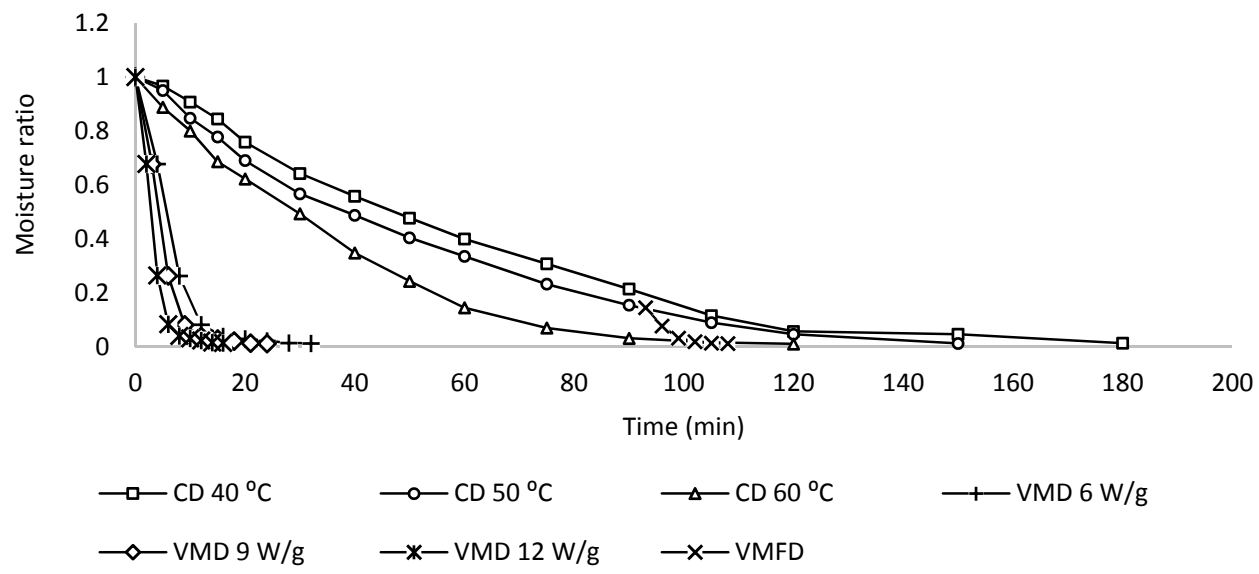

(a)

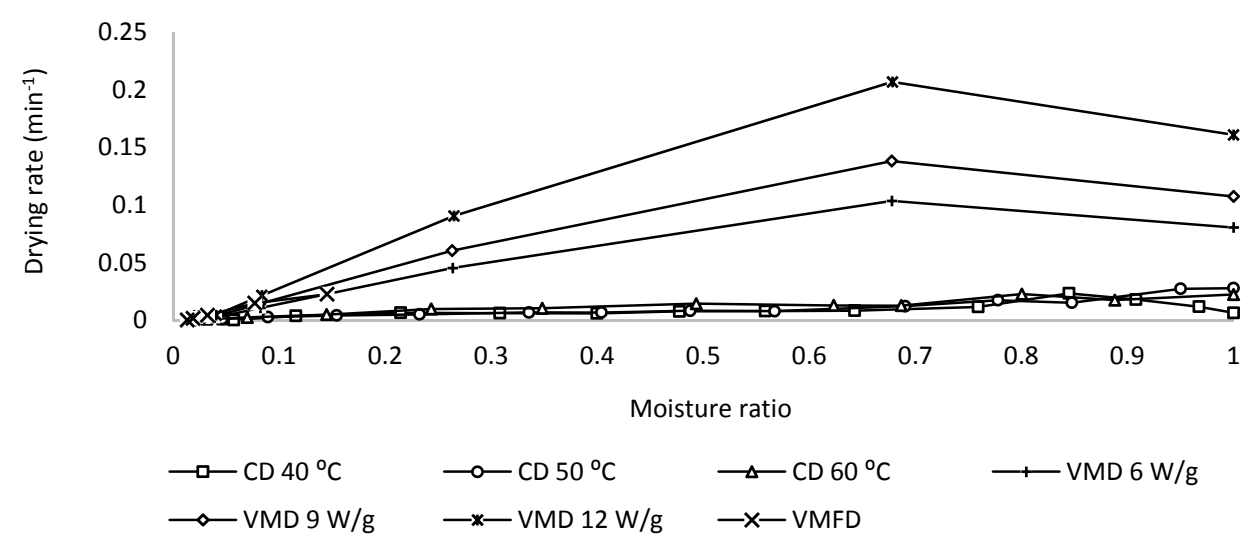

(b)

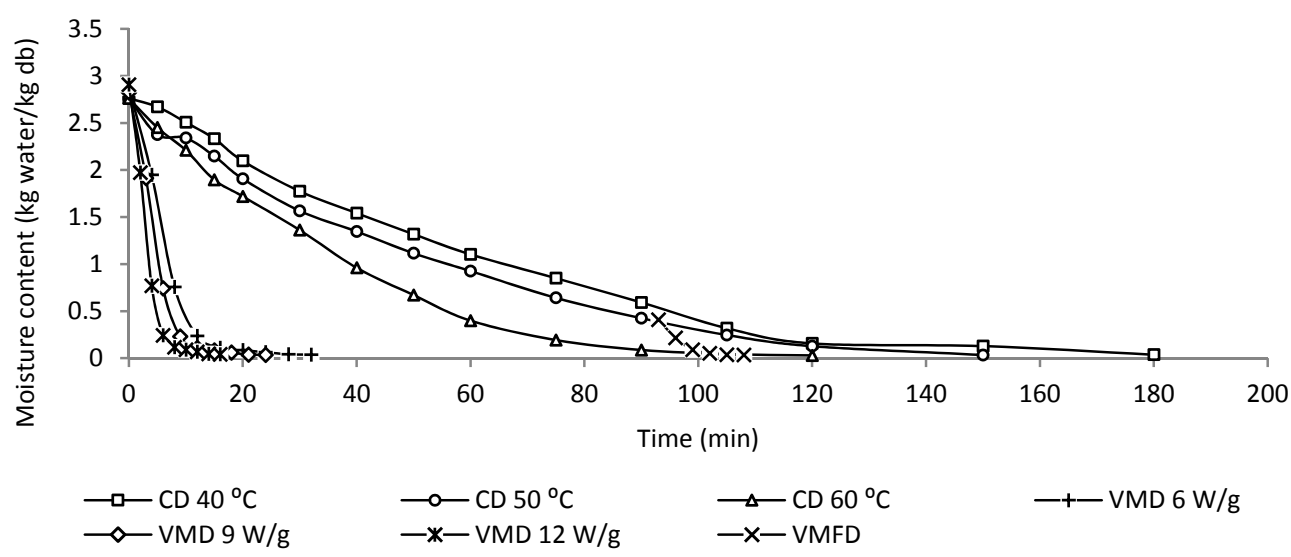

(c)

Figure 1. (a) Relationship between moisture ration (MR) and time. (b) Drying rate against MR. (c) Relationship between moisture content and time for the drying of $C$. alata at convective drying (CDs) at $40^{\circ} \mathrm{C}, 50^{\circ} \mathrm{C}$ and $60^{\circ} \mathrm{C}$, vacuum microwave drying (VMD) at 6,9 and $12 \mathrm{~W} / \mathrm{g}$ and convective pre-drying followed by vacuum microwave finish drying (CPD-VMFD) at $50{ }^{\circ} \mathrm{C}$ and $9 \mathrm{~W} / \mathrm{g}$. 


\subsection{Water Activity Analysis}

Water activity $a_{w}$ measures the degree of water that is bound to a food product and predicts the product's safety and stability with regard to microbial growth and the rates of chemical and biochemical reaction rates. The $a_{w}$ of fresh and dried $C$. alata leaves and the final moisture content of $C$. alata samples dried with CD, VMD and CPD-VMFD are shown in Table 1. The $a_{w}$ of the dried samples ranged from 0.1291 to 0.2836 . The $\mathrm{CD}$ at $60^{\circ} \mathrm{C}$ samples had the lowest final moisture content and significantly lower $a_{w}$ than other dried samples, which could be attributed to the high hot-air temperature applied and the longer drying duration than VMD and CPD-VMFD, thereby ensuring low residual moisture in the sample. Increasing temperature in $\mathrm{CD}$ resulted in lower $a_{w}$ and final moisture content. However, the application of different levels of microwave wattage showed no evident trends. Preferably, dried products should attain a low $a_{w}$ ranging from 0.60 to 0.80 because food spoilage bacteria and most moulds are inhibited below the $a_{w}$ of 0.91 and 0.80 , respectively [18]. In the present study, all of the drying treatments ensured microbiologically safe products. The determination of $a_{w}$ is also important in the prediction of biochemical reactions that may occur, knowing that Maillard reaction takes place at an optimum $\mathrm{a}_{\mathrm{w}}$ of 0.65 [19].

Table 1. Final moisture content and water activity of dried C. alata dehydrated using different methods.

\begin{tabular}{ccc}
\hline Drying Method & $\begin{array}{c}\text { Final Moisture Content } \\
\text { (kg water/ kg dw) }\end{array}$ & Water Activity $\boldsymbol{a}_{\boldsymbol{w}}$ \\
\hline $\mathrm{FD}$ & $0.0575 \pm 0.001$ & $0.2836 \pm 0.000 \mathrm{~b}$ \\
$\mathrm{CD}\left(40^{\circ} \mathrm{C}\right)$ & $0.0372 \pm 0.000$ & $0.2258 \pm 0.010 \mathrm{c}$ \\
$\mathrm{CD}\left(50^{\circ} \mathrm{C}\right)$ & $0.0336 \pm 0.001$ & $0.1558 \pm 0.004 \mathrm{f}$ \\
$\mathrm{CD}\left(60^{\circ} \mathrm{C}\right)$ & $0.0289 \pm 0.001$ & $0.1291 \pm 0.004 \mathrm{~g}$ \\
$\mathrm{VMD}(6 \mathrm{~W} / \mathrm{g})$ & $0.0372 \pm 0.003$ & $0.1905 \pm 0.002 \mathrm{~d}$ \\
$\mathrm{VMD}(9 \mathrm{~W} / \mathrm{g})$ & $0.0347 \pm 0.002$ & $0.1697 \pm 0.005 \mathrm{e}, \mathrm{f}$ \\
$\mathrm{VMD}(12 \mathrm{~W} / \mathrm{g})$ & $0.0423 \pm 0.002$ & $0.2200 \pm 0.003 \mathrm{c}$ \\
$\mathrm{CPD}-\mathrm{VMFD}$ & $0.0343 \pm 0.002$ & $0.1726 \pm 0.004 \mathrm{e}$ \\
\hline
\end{tabular}

FD—freeze drying; CD—convective drying, VMD—vacuum microwave drying, CPD—convective pre-drying, VMFD—vacuum microwave finish drying. Values with the same letter in the same column are not significantly different $(p<0.05)$, according to Tukey's test.

\subsection{Specific Energy Consumption}

The profiles of specific energy consumption shown in Figure 2a,b represent the amount of energy required to remove moisture from fresh leaves per $1 \mathrm{~g}$ of fresh weight and $1 \mathrm{~g}$ of water, respectively. Evidently, the shape of the curves suggests that drastic increments of specific energy consumptions are noted at the last stages of the drying process, irrespective of drying methods used. This result indicates that a considerable amount of energy is required to remove the same amount of water compared with the initial drying stages at a specific drying parameter. This behaviour is common in plant products with osmotic cellular structure that functions to limit the loss of moisture from plant tissues [18].

Figure $2 c$ presents the final specific energy consumptions of CD, VMD and CPD-VMFD. VMD achieved the lowest energy consumptions compared with CD methods, particularly at a high microwave wattage. However, practicality wise, the installation of a large-scale microwave vacuum dryer is costly. Combined drying, involving CD followed by VMFD, is highly recommended for industrial processes considering cost-effectiveness. Therefore, CPD-VMFD is deemed as a compromise between CD and VMD methods in terms of energy consumption requirement. In this study, CPD-VMFD achieved lower final specific energy consumption $\left(55.13 \mathrm{~kJ} / \mathrm{g}\right.$ fresh weight and $83.60 \mathrm{~kJ} / \mathrm{g}$ water) than $\mathrm{CD}$ at $50{ }^{\circ} \mathrm{C}$ $(82.06 \mathrm{~kJ} / \mathrm{g}$ fresh weight and $113.15 \mathrm{~kJ} / \mathrm{g}$ water) and slightly higher final specific energy consumption than VMD. CPD-VMFD achieved reduction in the final energy consumptions by $32.82 \%(\mathrm{~kJ} / \mathrm{g}$ fresh weight) and $26.12 \%\left(\mathrm{~kJ} / \mathrm{g}\right.$ water) in comparison with $\mathrm{CD}$ at $50{ }^{\circ} \mathrm{C}$. 


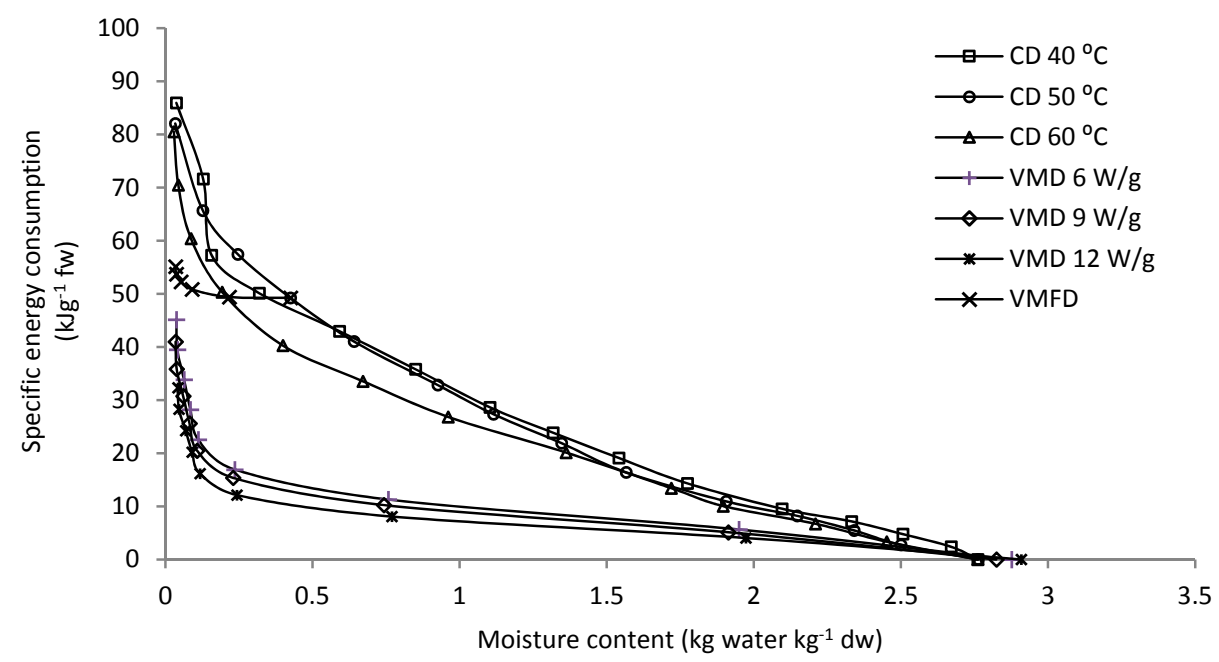

(a)

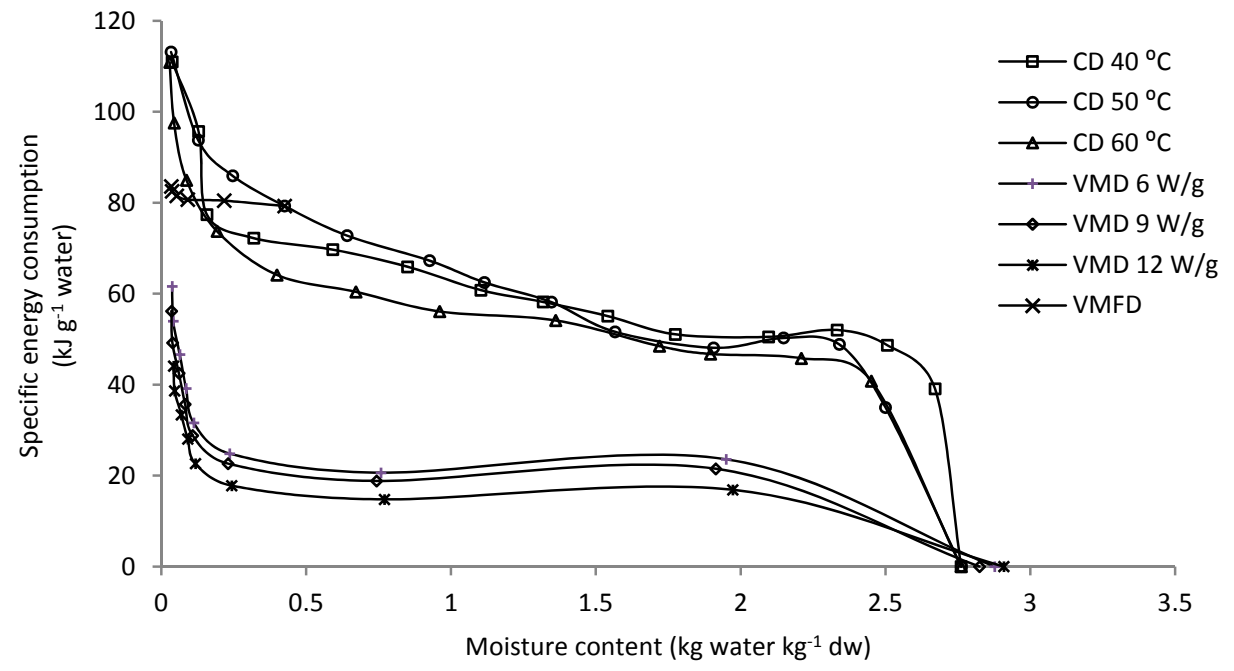

(b)

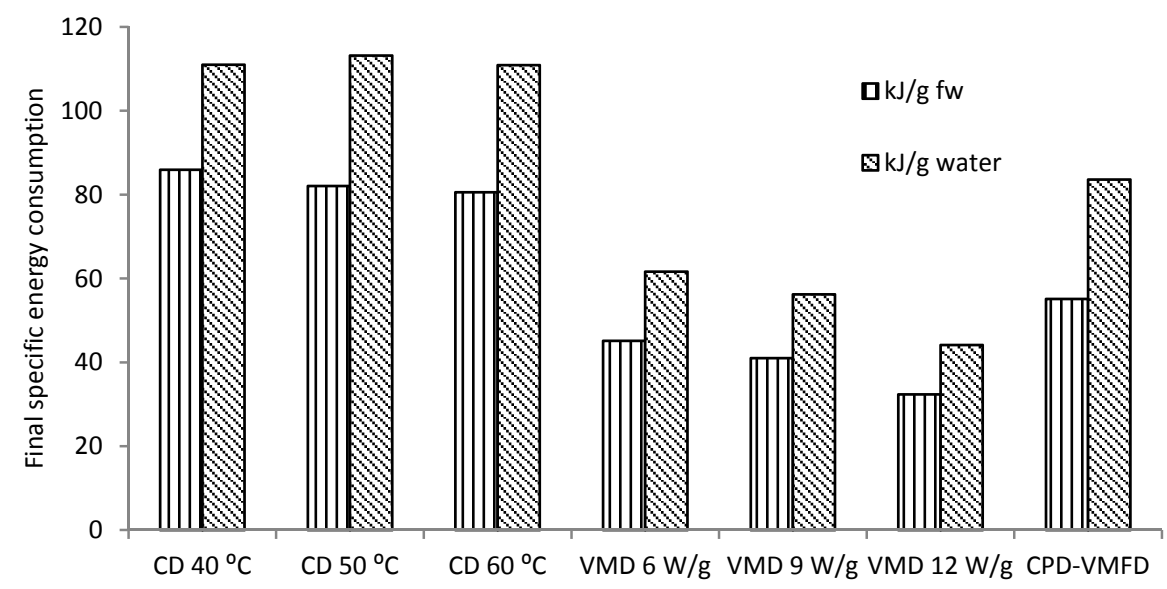

(c)

Figure 2. (a) Specific energy consumption of $C$. alata leaves per gram of fresh weight dried using $C D$, VMD and CPD-VMFD. (b) Specific energy consumption of C. alata leaves per gram of water removed using $C D$, VMD and CPD-VMFD. (c) Final specific energy consumptions of CD, VMD and CPD-VMFD of $C$. alata leaves. 


\subsection{Colour Analysis}

Dried leaves often appear slightly olive-brownish because drying results in the disruption of the cytoplasmic membrane, which leads to the release of cellular acids that degrade chlorophylls to pheophytins, with olive-brownish and greenish-coloured derivatives [20]. Table 2 shows the colour parameters of fresh and dried samples of $C$. alata affected by different drying methods and conditions. In this study, freeze-dried samples had the lightest colour, indicated by a high $L^{*}$ value, with the greenest (lowest $a^{*}$ value) and yellowest colour (highest $b^{*}$ value) amongst the other dried samples. Generally, convective-dried samples were darker in colour compared with VMD and CPD-VMFD samples. The microwave treatment proved effective in retaining the green colour and lightness of herbs due to the accelerated drying process coupled with a reduced oxygen condition. However, a low hot-air temperature of $40^{\circ} \mathrm{C}$ was also effective in preserving the green colour of the leaves. A high temperature applied during CD was observed to increase the degradation of chlorophylls (shown by the higher $a^{*}$ values), although the drying duration was reduced in comparison with CD at $40{ }^{\circ} \mathrm{C}$. FD achieved the highest $b^{*}$ value (yellow). The low-temperature drying process of FD is effective in preserving carotenoids, which are heat-sensitive. Moreover, VMD and CPD-VMFD were also effective in retaining carotenoids than $\mathrm{CD}$. Fresh samples appear darker with less yellow colour intensity because the high moisture in leaves may have led to the destruction of plant pigments during the time frame between the harvest process and analysis.

Table 2. Colour parameters $L^{*}, a^{*}$ and $b^{*}$ of $C$. alata influenced by different drying methods.

\begin{tabular}{cccc}
\hline \multirow{2}{*}{ Drying Conditions } & \multicolumn{3}{c}{ Colour Parameters } \\
\cline { 2 - 4 } & \multicolumn{1}{c}{$\boldsymbol{L}^{*}$} & $\boldsymbol{a}^{*}$ & $\boldsymbol{b}^{*}$ \\
\hline Fresh & $36.94 \pm 0.093 \mathrm{a}$ & $-2.75 \pm 0.451 \mathrm{a}$ & $9.04 \pm 0.440 \mathrm{a}$ \\
FD & $44.71 \pm 0.322 \mathrm{~b}$ & $-2.17 \pm 0.064 \mathrm{~b}$ & $17.00 \pm 0.320 \mathrm{~b}$ \\
$\mathrm{CD}\left(40^{\circ} \mathrm{C}\right)$ & $38.55 \pm 0.095 \mathrm{~b}$ & $-0.20 \pm 0.118 \mathrm{~d}, \mathrm{e}$ & $10.65 \pm 0.109 \mathrm{c}$ \\
$\mathrm{CD}\left(50^{\circ} \mathrm{C}\right)$ & $38.75 \pm 0.070 \mathrm{~b}$ & $0.00 \pm 0.056 \mathrm{e}, \mathrm{f}$ & $10.53 \pm 0.101 \mathrm{c}$ \\
$\mathrm{CD}\left(60^{\circ} \mathrm{C}\right)$ & $38.31 \pm 0.207 \mathrm{e}$ & $0.39 \pm 0.025 \mathrm{~g}$ & $10.04 \pm 0.186 \mathrm{~d}$ \\
VMD $(6 \mathrm{~W} / \mathrm{g})$ & $40.27 \pm 0.036 \mathrm{~d}$ & $0.45 \pm 0.044 \mathrm{~g}$ & $13.81 \pm 0.125 \mathrm{e}$ \\
VMD $(9 \mathrm{~W} / \mathrm{g})$ & $39.42 \pm 0.388 \mathrm{c}$ & $-0.47 \pm 0.051 \mathrm{c}, \mathrm{d}$ & $11.89 \pm 0.143 \mathrm{f}$ \\
VMD $(12 \mathrm{~W} / \mathrm{g})$ & $39.43 \pm 0.272 \mathrm{c}$ & $-0.54 \pm 0.042 \mathrm{c}$ & $12.25 \pm 0.115 \mathrm{f}$ \\
CPD-VMFD & $39.30 \pm 0.110 \mathrm{c}$ & $0.18 \pm 0.055 \mathrm{f}, \mathrm{g}$ & $11.82 \pm 0.149 \mathrm{f}$ \\
\hline
\end{tabular}

FD—freeze drying; CD—convective drying; VMD—vacuum microwave drying; CPD—convective pre-drying; VMFD—vacuum microwave finish drying; values with the same letter within a column are not significantly different $(p<0.05)$, according to Tukey's test.

\subsection{Antioxidant Activity and Total Phenolic Content (TPC) Analysis}

The analysis of antioxidant activity and TPC suggests a considerable reduction in radicals of 2,2'-azinobis(3-ethylbenzthiazoline-6-sulfonic acid) (ABTS), and $\mathrm{Fe}^{+3}$ to $\mathrm{Fe}^{+2}$ by FRAP methods and TPC values were observed after drying (Table 3). Amongst the drying treatments, the highest antioxidant activity and TPC values were observed for $\mathrm{CD}$ at $40^{\circ} \mathrm{C}$ and freeze-dried samples. C. alata dehydrated using $\mathrm{CD}$ at $40^{\circ} \mathrm{C}$ achieved higher antioxidant activity in comparison with VMD methods, although the ABTS and FRAP values of $\mathrm{CD}$ at $40^{\circ} \mathrm{C}$ was not significantly different than VMD methods (Table 3). This observation could be the result of polyphenols being exposed to oxygenated condition. Polyphenols in an intermediate oxidised state have been reported to show greater antioxidant effect compared with their non-oxidised state [21]. In addition, high-temperature stabilisation process could result in the production of Maillard reaction products (MRPs) formed from Maillard reaction in convective-dried samples. MRPs are known to exhibit antioxidant effect, often by chain breaking mechanism [22]. The assumption that MRPs could contribute to the overall increase in antioxidant activity of $\mathrm{CD}$ at $40{ }^{\circ} \mathrm{C}$ samples is supported by the lower $L^{*}$ values of convective-dried samples compared with VMD samples, which indicates more browning (Table 2). However, only at a low hot-air temperature $\left(40^{\circ} \mathrm{C}\right)$ was it effective in preserving the antioxidant properties of $C$. alata because 
the antioxidant activities were seen to decline at $50{ }^{\circ} \mathrm{C}$ and $60^{\circ} \mathrm{C}$. Samples dried using $\mathrm{CD}$ at $60^{\circ} \mathrm{C}$ produced the lowest ABTS, FRAP and TPC values. The high extent of loss in antioxidant values and phenolic content could be attributed to the high degradative temperature at $60{ }^{\circ} \mathrm{C}$. As for VMD, moderate microwave wattage of $9 \mathrm{~W} / \mathrm{g}$ was advantageous in achieving high antioxidant effect and TPC. Meanwhile, CPD-VMFD produced intermediate antioxidant activity and TPC values.

Table 3. Antioxidant activity and TPC of C. alata, influenced by various drying methods and conditions.

\begin{tabular}{|c|c|c|c|}
\hline \multirow{2}{*}{ Drying Method } & \multicolumn{2}{|c|}{ Antioxidant Activity ( $\mu \mathrm{M}$ Trolox/100 g dw) } & \multirow{2}{*}{$\begin{array}{l}\text { Total Phenolic Content } \\
(\mathrm{mg} / 100 \mathrm{~g} \mathrm{dw})\end{array}$} \\
\hline & ABTS & FRAP & \\
\hline Fresh & $65.53 \pm 4.97 a$ & $30.69 \pm 6.91 \mathrm{a}$ & $9368.59 \pm 1460.98 \mathrm{a}$ \\
\hline FD & $11.49 \pm 0.25 b, c$ & $5.34 \pm 0.17 b$ & $2883.05 \pm 146.45 b$ \\
\hline VMD $6 \mathrm{~W} / \mathrm{g}$ & $9.04 \pm 1.19 \mathrm{~b}, \mathrm{c}$ & $3.28 \pm 0.08 b$ & $1982.44 \pm 53.17 b$ \\
\hline VMD $9 \mathrm{~W} / \mathrm{g}$ & $11.29 \pm 1.03 b, c$ & $4.70 \pm 0.25 b$ & $2379.87 \pm 216.92 b$ \\
\hline VMD $12 \mathrm{~W} / \mathrm{g}$ & $9.15 \pm 1.70 \mathrm{~b}, \mathrm{c}$ & $5.39 \pm 0.38 b$ & $2441.91 \pm 82.86 \mathrm{~b}$ \\
\hline CPD-VMFD & $11.19 \pm 0.33 b, c$ & $5.01 \pm 0.18 b$ & $2413.36 \pm 277.94 b$ \\
\hline $\mathrm{CD}$ at $40^{\circ} \mathrm{C}$ & $13.54 \pm 0.02 c$ & $5.55 \pm 0.24 b$ & $2965.12 \pm 54.97 \mathrm{~b}$ \\
\hline $\mathrm{CD}$ at $50^{\circ} \mathrm{C}$ & $8.65 \pm 0.27 b, c$ & $3.88 \pm 0.58 b$ & $2342.75 \pm 74.18 b$ \\
\hline $\mathrm{CD}$ at $60^{\circ} \mathrm{C}$ & $7.43 \pm 0.63 b$ & $2.58 \pm 0.09 b$ & $1821.54 \pm 41.18 b$ \\
\hline
\end{tabular}

FD—freeze drying; CD—convective drying, VMD—vacuum microwave drying, CPD—convective pre-drying, VMFD—vacuum microwave finish drying. Values with the same letter in the same column are not significantly different $(p<0.05)$ according to Tukey's test.

The TPC values are shown in Table 3. All drying treatments resulted in large reduction in TPC values, with $\mathrm{CD}$ at $60^{\circ} \mathrm{C}$ obtaining the lowest TPC value, whilst $\mathrm{CD}$ at $40{ }^{\circ} \mathrm{C}$ achieved the highest TPC. Low TPC values of the heat-treated samples may be caused by the oxidative and thermal degradation of phenolic compounds. The results showed that $\mathrm{CD}$ at $40{ }^{\circ} \mathrm{C}$ could preserve phenolic compounds better than freeze drying (FD), contrary to the understanding that FD, a low-temperature dehydration method, could preserve high amounts of phenolic compounds. However, a previous report has suggested that FD treatment may not have deactivated degradative enzymes completely because of the low-temperature dehydration process. This could lead to the reactivation of degradative enzymes when freeze-dried samples are exposed to moisture in the air [23]. This is supported by the result obtained by Li et al. [24], which investigated the thermal inactivation kinetics of polyphenol oxidase (PPO) of chicory leaves. It was found that the residual activities of PPO at the end of hot air drying was considerably lower than that of FD, which indicates that hot air drying was more effective in the inactivation of PPO compared to FD, inhibiting enzymatic oxidative reactions to an extent. It was suggested that enzymatic oxidative reaction is more likely to occur during FD as the formation of ice crystals in the tissue matrix of the raw material will lead to cell rupture, subsequently exposing phenolic species to oxidative conditions. However, most studies have shown that FD is able to preserve phenolic compounds better than hot air drying, in the case of oregano leaves [25], strawberry [21] and citrus fruits [26]. Therefore, the influence of a particular drying method on the preservation of phenolic compounds is difficult to predict and is dependent on the specific compounds and the particular plant material involved.

Overall, the antioxidant activity values failed to correlate well with TPC values. Thus, antioxidants other than phenolic compounds could have contributed to the total antioxidant activity (terpene compounds) contained in volatiles, phytosterols and fatty acid constituents in C. alata. For example, terpenes contained in C. alata (such as citronellol, linalool and fenchone; Figure 3) are amongst the identified terpenes that could contribute to the total antioxidant activity. This result is based on the fact that terpenes have been reported to be potential antioxidant compounds because of their capability to interact with free radicals. The antioxidant potential of terpenes is suggested to be similar to flavonoids, and their antioxidant effect depends on the structural characteristics such as the presence of hydroxyl groups, multiple bonds, conjugated systems and phenolic structure [27]. 


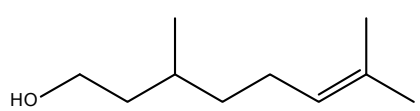

Citronellol

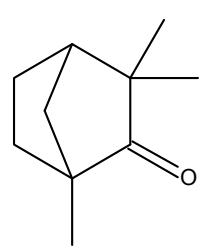

Fenchone

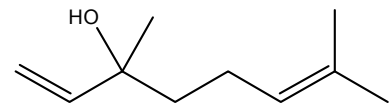

Linalool

Figure 3. Chemical structures of citronellol, fenchone and linalool.

The interactions amongst antioxidants resulting in higher antioxidant effect has been widely reported and acknowledged because enhanced antioxidant effect is evident when antioxidants are combined than when isolated [28-30]. This phenomenon is termed as synergism, which results in the higher net interactive antioxidant activity compared with the sum of antioxidant activities exerted by individual antioxidants. Synergism occurs when (i) an antioxidant can donate electrons to other antioxidants, thereby facilitating their regeneration; (ii) when an antioxidant exerts protection on another antioxidant by sacrificial self-oxidation; and when (iii) two or more antioxidants exhibit antioxidant mechanisms [31]. However, future studies are needed to correctly ascertain the interactions between antioxidants in C. alata and it remains to be confirmed if certain combinations of primary antioxidants present in C. alata will lead to an overall greater antioxidant effect. The type of interactions between antioxidants is important to determine if the extract of $C$. alata is to be used as a potential source of antioxidant compounds. Future studies should also include development of drying procedures by incorporation of other methods of drying or some pre-treatment in order to preserve the largest possible amount of native compounds responsible for bioactive potential.

\subsection{Analysis of Volatile Content}

Volatile constituents of fresh and dried C. alata, which were extracted using HS-SPME and analysed with GC-MS, revealed the presence of 50 volatile compounds. Table 4 presents the identified volatile compounds and the respective concentrations. The total concentration of volatiles in fresh C. alata

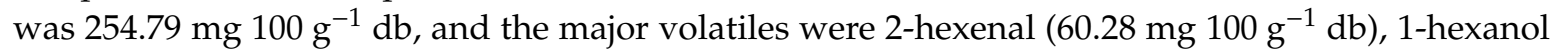

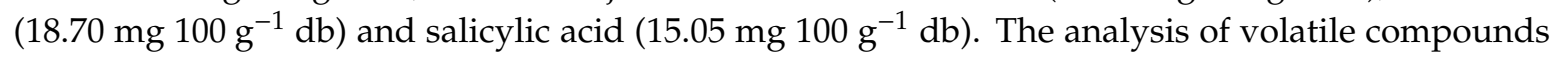
showed that high losses of volatile content followed after drying; however, some drying methods could retain higher volatile content.

Majority of volatile compounds were present in the dried sample but differed in their concentrations, with respect to the different drying methods and conditions. In the case of FD, losses of volatiles were higher than expected; however, the loss of volatile constituents during FD was linked to the sublimation of water during the process. The pressure in the chamber should be increased slightly to reduce the loss of volatiles during FD, as reported by Calin-Sanchez et al. (2011) who stated that losses of volatiles is a result of the reduction in the pressure of drying chamber [32].

With regard to $C D$, huge differences in volatile content were observed when hot-air temperature was varied. A low application of temperature $\left(\mathrm{CD}\right.$ at $\left.40{ }^{\circ} \mathrm{C}\right)$ led to a high retention of volatiles. The total concentration of volatiles decreased from $61.85 \mathrm{mg} 100 \mathrm{~g}^{-1} \mathrm{db}$ to $34.55 \mathrm{mg} 100 \mathrm{~g}^{-1} \mathrm{db}_{\text {when }}$ temperature was increased from $40{ }^{\circ} \mathrm{C}$ to $60^{\circ} \mathrm{C}$. This trend is noted considering individual volatile compounds-with concentrations being high when low temperature was applied. However, the concentration of some volatiles, such as $\beta$-cubebene, 2-undecanone and citronellol, failed to follow this trend. The respective concentrations of these volatiles at $60^{\circ} \mathrm{C}$ were higher in comparison with $50{ }^{\circ} \mathrm{C}$. With VMD, increasing the microwave wattage from $6 \mathrm{~W} / \mathrm{g}$ to $12 \mathrm{~W} / \mathrm{g}$ in VMD resulted in the increase of

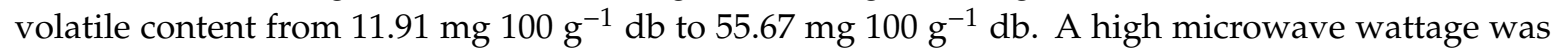
beneficial because the increased drying intensity effectively reduced the total drying time, and volatiles were less exposed to the high degradative temperature. 
Table 4. Concentration of volatile compounds influenced by various drying methods and conditions.

\begin{tabular}{|c|c|c|c|c|c|c|c|c|c|c|c|c|}
\hline \multirow{2}{*}{ Compound } & \multirow{2}{*}{ RT } & \multicolumn{2}{|c|}{ Retention Indexes } & \multicolumn{9}{|c|}{ Concentration $\left(\mathrm{mg} 100 \mathrm{~g}^{-1} \mathrm{db}\right)$} \\
\hline & & Exp & Lit & Fresh & FD & $\begin{array}{c}\text { CD } \\
\left(40^{\circ} \mathrm{C}\right)\end{array}$ & $\begin{array}{c}\text { CD } \\
\left(50^{\circ} \mathrm{C}\right)\end{array}$ & $\begin{array}{c}\text { CD } \\
\left(60^{\circ} \mathrm{C}\right)\end{array}$ & $\begin{array}{l}\text { VMD } \\
(6 \mathrm{~W} / \mathrm{g})\end{array}$ & $\begin{array}{l}\text { VMD } \\
(9 \mathrm{~W} / \mathrm{g})\end{array}$ & $\begin{array}{c}\text { VMD } \\
\text { (12 W/g) }\end{array}$ & CPD-VMFD \\
\hline 2-Hexenal & 4.770 & 843 & 851 & 60.28 & 2.98 & 7. 19 & 5.57 & 6.71 & 0.45 & 1.07 & 4.89 & 2.13 \\
\hline 2-Hexen-1-ol, (E)- & 5.030 & 858 & 862 & 10.11 & 0.65 & 0.82 & 0.50 & 0.38 & 0.00 & 0.18 & 1.66 & 0.31 \\
\hline 1-Hexanol & 5.070 & 861 & 868 & 18.70 & 1.85 & 0.78 & 0.62 & 0.80 & 0.02 & 0.95 & 6.37 & 0.43 \\
\hline 2-Heptanol & 5.810 & 899 & 901 & 1.62 & 0.33 & 1.37 & 0.58 & 0.80 & 0.16 & 0.20 & 1.11 & 0.37 \\
\hline Anisole & 6.330 & 917 & 920 & 1.29 & 0.47 & 0.38 & 0.17 & 0.11 & 0.01 & 0.03 & 0.24 & 0.09 \\
\hline Benzaldehyde & 7.500 & 959 & 962 & 8.37 & 0.91 & 1.99 & 0.71 & 0.65 & 0.10 & 0.21 & 1.10 & 0.31 \\
\hline 1-Octen-3-ol & 8.180 & 883 & 880 & 2.75 & 0.24 & 1.67 & 1.02 & 0.07 & 0.00 & 0.18 & 1.15 & 0.04 \\
\hline Phenol & 8.100 & 980 & 980 & 5.02 & 1.02 & 0.96 & 0.32 & 0.09 & 0.08 & 0.38 & 1.00 & 0.24 \\
\hline 5-Hepten-2-one, 6-methyl- & 8.260 & 986 & 986 & 4.62 & 1.08 & 3.46 & 2.40 & 2.12 & 0.48 & 1.34 & 7.50 & 1.18 \\
\hline 3-Octanol & 8.430 & 992 & 994 & 3.68 & 0.46 & 1.01 & 0.76 & 1.10 & 0.19 & 0.23 & 1.60 & 0.34 \\
\hline 5-Hepten-2-ol, 6-methyl- & 8.570 & 997 & 994 & 1.19 & 0.01 & 0.07 & 0.02 & 0.07 & 0.00 & 0.10 & 0.91 & 0.00 \\
\hline Hexanoic acid, ethyl ester & 8.670 & 1000 & 1000 & 2.21 & 1.33 & 2.47 & 0.51 & 1.27 & 0.16 & 0.42 & 2.63 & 0.16 \\
\hline Octanal & 8.750 & 1002 & 1003 & 0.50 & 0.53 & 0.23 & 0.27 & 0.41 & 0.12 & 0.06 & 0.24 & 0.02 \\
\hline Anisole, o-methyl- & 9.000 & 1010 & 1009 & 0.95 & 0.05 & 0.28 & 0.12 & 0.16 & 0.02 & 0.06 & 0.31 & 0.05 \\
\hline Acetic acid, hexyl ester & 9.100 & 1013 & 1011 & 0.36 & 0.06 & 0.02 & 0.00 & 0.00 & 0.01 & 0.01 & 0.07 & 0.00 \\
\hline 4-Hepten-1-ol, 6-methyl- & 9.230 & 1017 & 1020 & 3.36 & 0.14 & 0.35 & 0.36 & 0.29 & 0.01 & 0.04 & 0.16 & 0.18 \\
\hline 3-Ethyl-4-methylpentan-1-ol & 9.320 & 1020 & 1023 & 8.47 & 0.50 & 2.11 & 0.78 & 0.87 & 0.06 & 0.15 & 0.59 & 0.35 \\
\hline p-Cymene & 9.470 & 1024 & 1025 & 1.18 & 0.04 & 0.68 & 0.14 & 0.17 & 0.09 & 0.10 & 0.37 & 0.07 \\
\hline Limonene & 9.610 & 1029 & 1030 & 2.18 & 0.05 & 0.22 & 0.15 & 0.13 & 0.05 & 0.17 & 1.25 & 0.41 \\
\hline Eucalyptol & 9.700 & 1031 & 1032 & 1.92 & 0.00 & 0.00 & 0.02 & 0.01 & 0.00 & 0.00 & 0.02 & 1.88 \\
\hline Benzyl alcohol & 9.800 & 1035 & 1036 & 13.42 & 2.92 & 4.67 & 2.81 & 2.86 & 0.49 & 1.22 & 4.36 & 0.01 \\
\hline Benzeneacetaldehyde & 10.070 & 1042 & 1045 & 3.28 & 0.96 & 0.89 & 0.48 & 0.63 & 0.06 & 0.37 & 0.98 & 0.28 \\
\hline Ether, benzyl ethyl & 10.500 & 1056 & 1046 & 2.51 & 0.24 & 0.17 & 0.08 & 0.12 & 0.02 & 0.13 & 0.14 & 0.02 \\
\hline Fenchone & 11.580 & 1088 & 1096 & 7.99 & 0.22 & 0.57 & 0.16 & 0.02 & 0.02 & 0.04 & 1.18 & 0.05 \\
\hline 2-Nonanone & 11.660 & 1091 & 1092 & 1.01 & 0.08 & 0.40 & 0.02 & 0.10 & 0.00 & 0.04 & 0.32 & 0.04 \\
\hline Ethyl (4E)-4-heptenoate & 11.740 & 1094 & 1090 & 3.63 & 0.64 & 1.03 & 0.53 & 0.67 & 0.04 & 0.06 & 0.26 & 0.01 \\
\hline Linalool & 11.960 & 1100 & 1099 & 10.59 & 0.75 & 2.95 & 1.26 & 1.20 & 0.13 & 0.33 & 1.80 & 0.46 \\
\hline Nonanal & 12.080 & 1104 & 1104 & 2.81 & 0.16 & 0.91 & 0.45 & 0.86 & 0.09 & 0.27 & 0.97 & 0.15 \\
\hline$\beta$-Thujone & 12.180 & 1107 & 1114 & 1.12 & 0.70 & 0.66 & 0.44 & 0.59 & 0.07 & 0.39 & 1.11 & 0.20 \\
\hline Phenylethyl alcohol & 12.440 & 1114 & 1116 & 1.82 & 0.42 & 3.90 & 0.80 & 0.83 & 0.00 & 0.20 & 1.60 & 0.08 \\
\hline 3-Thujanone & 12.560 & 1118 & 1119 & 1.01 & 0.69 & 0.66 & 1.01 & 1.17 & 0.09 & 0.67 & 2.20 & 0.15 \\
\hline Veratrol & 13.540 & 1147 & 1148 & 6.49 & 0.47 & 1.65 & 0.44 & 0.54 & 0.10 & 0.14 & 0.62 & 0.23 \\
\hline 2,6-Nonadienal, (E,Z)- & 13.770 & 1153 & 1155 & 5.75 & 0.21 & 0.72 & 0.24 & 0.32 & 0.01 & 0.08 & 0.13 & 0.12 \\
\hline 2-Nonenal, (E)- & 14.000 & 1160 & 1162 & 0.39 & 0.34 & 1.48 & 0.68 & 0.71 & 0.09 & 0.20 & 0.00 & 0.36 \\
\hline endo-Borneol & 14.260 & 1167 & 1167 & 0.32 & 0.31 & 1.13 & 0.39 & 0.66 & 0.10 & 0.06 & 0.25 & 0.29 \\
\hline Hexanoic acid, butyl ester & 15.070 & 1191 & 1189 & 1.20 & 0.03 & 0.06 & 0.04 & 0.08 & 0.01 & 0.02 & 0.15 & 0.03 \\
\hline
\end{tabular}


Table 4. Cont.

\begin{tabular}{|c|c|c|c|c|c|c|c|c|c|c|c|c|}
\hline \multirow{2}{*}{ Compound } & \multirow{2}{*}{ RT } & \multicolumn{2}{|c|}{ Retention Indexes } & \multicolumn{9}{|c|}{ Concentration (mg $\left.100 \mathrm{~g}^{-1} \mathrm{db}\right)$} \\
\hline & & Exp & Lit & Fresh & FD & $\begin{array}{c}\text { CD } \\
\left(40^{\circ} \mathrm{C}\right)\end{array}$ & $\begin{array}{l}\mathrm{CD} \\
\left(50^{\circ} \mathrm{C}\right)\end{array}$ & $\begin{array}{l}\mathrm{CD} \\
\left(60^{\circ} \mathrm{C}\right)\end{array}$ & $\begin{array}{l}\text { VMD } \\
(6 \mathrm{~W} / \mathrm{g})\end{array}$ & $\begin{array}{l}\text { VMD } \\
(9 \mathrm{~W} / \mathrm{g})\end{array}$ & $\begin{array}{l}\text { VMD } \\
(12 \mathrm{~W} / \mathrm{g})\end{array}$ & CPD-VMFD \\
\hline Methyl salicylate & 15.200 & 1195 & 1192 & 5.18 & 0.27 & 1.18 & 0.06 & 0.78 & 0.17 & 0.02 & 0.23 & 0.38 \\
\hline 2-Octynoic acid, methyl ester & 15.550 & 1210 & 1212 & 2.91 & 0.16 & 0.73 & 0.49 & 0.50 & 0.04 & 0.15 & 0.53 & 0.25 \\
\hline Citronellol & 16.330 & 1228 & 1228 & 13.26 & 0.93 & 2.96 & 1.28 & 1.91 & 0.02 & 0.20 & 0.06 & 0.81 \\
\hline $\begin{array}{c}\text { Butanoic acid, 2-methyl-, hexyl } \\
\text { ester }\end{array}$ & 16.650 & 1238 & 1236 & 1.56 & 0.21 & 1.19 & 0.38 & 0.49 & 0.07 & 0.21 & 0.70 & 0.23 \\
\hline D-Carvone & 16.900 & 1245 & 1246 & 0.65 & 0.22 & 0.90 & 0.27 & 0.32 & 0.06 & 0.13 & 0.80 & 0.19 \\
\hline Salicylic acid, ethyl ester & 17.850 & 1274 & 1270 & 15.05 & 0.58 & 1.32 & 0.61 & 0.60 & 0.07 & 0.15 & 0.70 & 0.27 \\
\hline 2-Undecanone & 18.480 & 1293 & 1294 & 2.62 & 0.01 & 2.13 & 0.17 & 0.48 & 0.06 & 0.03 & 0.51 & 0.01 \\
\hline Nonanoic acid, ethyl ester & 18.620 & 1296 & 1296 & 0.55 & 0.01 & 0.15 & 0.01 & 0.05 & 0.00 & 0.00 & 0.04 & 0.00 \\
\hline Methyl 4-methylsalicylate & 19.270 & 1319 & - & 1.86 & 0.17 & 0.28 & 0.15 & 0.09 & 0.02 & 0.15 & 0.18 & 0.08 \\
\hline$\beta$-Cubebene & 21.400 & 1391 & 1389 & 2.54 & 0.08 & 1.38 & 0.56 & 0.87 & 0.04 & 0.28 & 0.84 & 0.35 \\
\hline Geranyl acetone & 22.800 & 1457 & 1453 & 0.86 & 0.10 & 0.33 & 0.18 & 0.25 & 0.04 & 0.12 & 0.35 & 0.13 \\
\hline trans- $\beta$-Ionone & 23.440 & 1489 & 1486 & 2.59 & 0.24 & 0.80 & 0.48 & 0.51 & 0.07 & 0.27 & 0.78 & 0.23 \\
\hline Widdrol & 25.450 & 1618 & 1610 & 1.92 & 0.02 & 0.08 & 0.03 & 0.00 & 0.00 & 0.01 & 0.04 & 0.01 \\
\hline Isopropyl myristate & 27.400 & 1825 & 1827 & 1.10 & 0.05 & 0.53 & 0.22 & 0.13 & 0.07 & 0.11 & 0.68 & 0.06 \\
\hline TOTAL & & & & $254.79 \mathrm{a}$ & $24.91 \mathrm{c}$ & $61.85 \mathrm{~b}$ & $29.73 c$ & $34.55 \mathrm{c}$ & $11.91 \mathrm{~d}$ & $11.93 \mathrm{~d}$ & $55.67 \mathrm{~b}$ & $14.04 \mathrm{c}, \mathrm{d}$ \\
\hline
\end{tabular}

RT—retention time; RI—retention index; Exp—experimental; Lit—literature; FD—freeze drying; CD—convective drying; VMD—vacuum microwave drying; CPD—convective pre-drying;

VMFD—vacuum microwave finish drying; nd—not detected. ${ }^{a}$ NS, not significant F ratio $(p<0.05)$; ${ }^{b}$ Treatment means of the ANOVA test; Values followed by the same letter, within the

same row, are not significantly different $(p<0.05)$, according to Tukey's multiple-range test. 


\subsection{Phytosterol Analysis}

Preliminary studies have shown that CPD-VMFD and CD $50^{\circ} \mathrm{C}$ guaranteed high phytosterol yield. Thus, CPD-VMFD and $\mathrm{CD}$ at $50^{\circ} \mathrm{C}$ were used to determine the effect of drying on the concentration of phytosterols in the present study. Table 5 shows the phytosterols in C. alata and their respective concentrations. The total concentrations of phytosterols in fresh sample amounted to $3647.48 \mathrm{mg}$ $100 \mathrm{~g}^{-1} \mathrm{db}$. The major phytosterols present in fresh and dried samples were $\beta$-sitosterol, followed by stigmasterol and campesterol. CPD-VMFD was expected to retain a higher concentration of

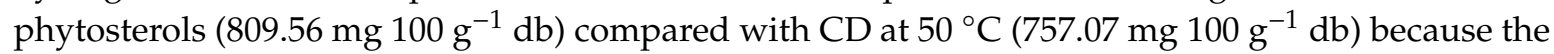
low temperature and reduced oxygen condition during the microwave treatment during VMFD could have lessen the thermo-oxidation of phytosterols. This result coincides with the findings of Soupas et al. (2004) and Rudzińska, Przybylski and Wąsowicz (2009), who reported that high drying temperature and prolonged drying time can decrease phytosterol concentration [33,34]. Numerous factors, such as process conditions (including heating time, temperature and phytosterol chemical structure), could affect the oxidative stability of the compound. However, the high losses of phytosterols in C. alata in comparison with the phytosterol content of fresh sample were probable due to the oxidation process and heat degradation.

Table 5. Concentration of phytosterols influenced by drying methods.

\begin{tabular}{|c|c|c|c|c|c|}
\hline \multirow{2}{*}{ Compound } & \multirow{2}{*}{ Retention time } & \multirow{2}{*}{ ANOVA } & Fresh & CPD-VMFD & $\mathrm{CD}$ at $50^{\circ} \mathrm{C}$ \\
\hline & & & \multicolumn{3}{|c|}{ Concentration (mg $100 \mathrm{~g}^{-1} \mathrm{db}$ ) } \\
\hline$\alpha$-tocopherol & 25.945 & n.s. ${ }^{a}$ & $106.08 \mathrm{a}$ & $106.32 \mathrm{a}$ & $85.85 \mathrm{a}, \mathrm{b}$ \\
\hline Desmosterol & 26.630 & $* * *$ & $218.08 \mathrm{a}$ & $37.74 \mathrm{~b}$ & $42.23 \mathrm{~b}$ \\
\hline Lanosterol & 26.875 & $* * *$ & $152.20 \mathrm{a}$ & $19.84 \mathrm{~b}$ & $22.33 \mathrm{~b}$ \\
\hline Campesterol & 27.575 & $* * *$ & $498.76 \mathrm{a}$ & $128.45 \mathrm{~b}$ & $132.60 \mathrm{~b}$ \\
\hline Stigmasterol & 28.035 & $* * *$ & $1001.48 \mathrm{a}$ & $221.47 \mathrm{~b}$ & $193.81 \mathrm{~b}$ \\
\hline$\beta$-sitosterol & 28.950 & $* * *$ & $1162.24 \mathrm{a}$ & $282.31 \mathrm{~b}$ & $264.62 \mathrm{~b}$ \\
\hline$\beta$-amyrin & 29.195 & $* * *$ & $268.82 \mathrm{a}$ & $2.78 \mathrm{~b}$ & $2.31 \mathrm{~b}$ \\
\hline Cycloartenol & 30.045 & $* * *$ & $67.20 \mathrm{a}$ & $0.00 \mathrm{~b}$ & $0.93 \mathrm{~b}$ \\
\hline Betulin & 31.250 & $* * *$ & $176.62 \mathrm{a}$ & $10.64 \mathrm{~b}$ & $12.38 \mathrm{~b}$ \\
\hline TOTAL & & & $3647.48 \mathrm{a}$ & $809.56 \mathrm{~b}$ & $757.07 \mathrm{~b}$ \\
\hline
\end{tabular}

CPD-convective pre-drying; VMFD—vacuum microwave finish drying; CD-convective drying. ${ }^{a}$ NS, not significant $\mathrm{F}$ ratio $(p<0.05) ;{ }^{\mathrm{b}}$ Treatment means of the ANOVA test (values are the mean value of three replicates); values followed by the same letter, within the same row, is not significantly different $(p<0.05)$ according to Tukey's multiple-range test.

\subsection{Fatty Acid Analysis}

Thermal drying has been reported to have a minor influence on the concentration of fatty acids because the structure of fatty acids remained stable at a high temperature of $325^{\circ} \mathrm{C}$ [35]. In another study, negligible amount of fatty acids was degraded when thermally treated at $90{ }^{\circ} \mathrm{C}$ for $30 \mathrm{~min}$ [36]. Therefore, in the present study, the drying temperatures applied could be assumed to possess minor degradative effect. Table 6 shows the identified fatty acids and their relative abundance determined with GC-MS analysis. $\alpha$-Linolenic acid was the major fatty acid present, followed by linoleic and palmitic acids. $\alpha$-Linolenic acid is an antioxidant, a plant-derived omega- 3 fatty acid and is known for its role in mediating cardiovascular disease [37]. 
Table 6. Fatty acid composition of C. alata.

\begin{tabular}{ccc}
\hline Compound & Retention Time & Total Area \% \\
\hline Lauric acid & 23.505 & $0.16 \pm 0.11$ \\
Myristic acid & 27.805 & $1.34 \pm 0.31$ \\
Pentadecanoic acid & 29.820 & $0.24 \pm 0.08$ \\
Palmitic acid & 31.745 & $20.59 \pm 5.7$ \\
Palmitoleic acid & 32.135 & $2.03 \pm 0.37$ \\
Hexadecenoic acid, & 32.655 & $0.91 \pm 0.15$ \\
methyl ester, (11Z)- & 33.590 & $0.49 \pm 0.09$ \\
Heptadecanoic acid & 33.925 & $0.18 \pm 0.05$ \\
cis-10-Heptadecenoic acid & 35.365 & $4.47 \pm 0.8$ \\
Stearic acid & 35.640 & $8.28 \pm 0.21$ \\
Oleic acid & 35.760 & $0.40 \pm 0.14$ \\
Elaidic acid & 36.375 & $23.07 \pm 3.12$ \\
Linoleic acid & 37.410 & $34.78 \pm 5.17$ \\
$\alpha$-Linolenic acid & 38.675 & $0.97 \pm 0.31$ \\
Arachidic acid & 41.160 & $1.86 \pm 0.65$ \\
Behenic acid & 42.345 & $0.23 \pm 0.19$ \\
cis-4,7,10,13,16,19- & & \\
Docosahexaenoic acid & &
\end{tabular}

\section{Materials and Methods}

\subsection{Chemicals and Reagents}

ABTS, FRAP reagent, acetate buffer, Folin-Ciocalteu reagent, gallic acid, sodium carbonate, acetic acid, 2,4,6-tripyridyl-1,3,5-triazine (TPTZ), potassium persulfate, 6-hydroxy-2,5,7,8-tetramethylchroman-2-carboxylic acid (Trolox), $\mathrm{BF}_{3} / \mathrm{MeOH}$, potassium hydroxide, p-methoxyphenol, chloroform/(folsch), hexane, sodium chloride, methanol, magnesium sulphate, pyridine, hydrochloric acid $(\mathrm{HCl})$ and $\mathrm{N}, \mathrm{O}$-bis(trimethylsilyl)trifluoroacetamide (BSTFA) were purchased from Sigma-Aldrich (Steinheim, Germany).

\subsection{Plant Material Preparation}

The leaves of $C$. alata were purchased from TKC herbal plantation (Seremban, Malaysia). Identification was confirmed at the Forest Research Institute of Malaysia with voucher specimen: 047/17. The initial moisture content in the range from $2.761 \mathrm{~kg}$ water $/ \mathrm{kg}$ dw to $3.645 \mathrm{~kg}$ water $/ \mathrm{kg} \mathrm{dw}$ was determined by drying fresh leaves to a constant mass using a vacuum oven dryer at a temperature of $60{ }^{\circ} \mathrm{C}$ for $24 \mathrm{~h}$. In this study, C. alata leaves were segregated into $40 \mathrm{~g}$ portions and dried using four drying methods. Dying process was stopped when the mass loss of consecutive dried leaves was $0.05 \mathrm{~g}$ or less. A blender was used to ground the dried leaves into a fine powder.

\subsection{Drying Methods}

\subsection{1. $\mathrm{CD}$}

Leaves of $C$. alata were dried using a convective hot-air dryer designed and constructed at the Institute of Agricultural Engineering (Wroclaw, Poland) at $40^{\circ} \mathrm{C}, 50^{\circ} \mathrm{C}$ and $60^{\circ} \mathrm{C}$ with an air velocity of $0.5 \mathrm{~ms}^{-1}$.

\subsubsection{VMD}

The leaves were dried with a vacuum microwave dryer (Plazmatronika, Wroclaw, Poland) equipped with a cylindrical drum, connected to a vacuum system and was rotated at $6 \mathrm{rpm}$ throughout the course of drying. The dryer was equipped with a fan that provided a stream of air with a velocity of $1 \mathrm{~ms}^{-1}$ to avoid local overheating. Three microwave power levels $(6,9$ and $12 \mathrm{~W} / \mathrm{g})$ and pressures 
ranging from $4 \mathrm{kPa}$ to $6 \mathrm{kPa}$ was applied in this study. Leaves were periodically taken out from the dryer to measure the maximum temperature of dried leaves with an i50 infrared camera (Flir Systems $\mathrm{AB}$, Portland, OR, USA).

\subsubsection{Two-Stage Drying: CPD-VMFD}

Leaves were pre-dried with a convective hot-air dryer similar to Section 3.3 .1 at $50{ }^{\circ} \mathrm{C}$ and drying was stopped after $90 \mathrm{~min}$ at a moisture content of $0.425 \mathrm{~kg}$ water $\mathrm{kg}^{-1} \mathrm{dw}$. The leaves were finished and dried with a vacuum microwave dryer (Plazmatronika, Wroclaw, Poland) at $9 \mathrm{~W} / \mathrm{g}$.

\subsubsection{FD}

Leaves were freeze-dried using a freeze dryer OE-950 (Labor, MIM, Budapest, Hungary) at a temperature of $-60^{\circ} \mathrm{C}$ and pressure of $65 \mathrm{~Pa}$. The heating plate reached a temperature of $30^{\circ} \mathrm{C}$ for sublimation process to occur. Freeze-dried samples were used as control samples in this study.

\subsection{Modelling of Drying Kinetics}

The drying kinetics of $C$. alata leaves dried with CD, VMD and CPD-VMFD were based on the mass losses of samples. The MR of $C$. alata leaves was determined as follows:

$$
M R=\frac{M(t)-M_{e}}{M_{0}-M_{e}}
$$

where $M(t)$ is the moisture content ( $\mathrm{kg}$ water $/ \mathrm{kg}$ dry matter $(\mathrm{dm}))$ after drying time $t, M_{e}$ is the equilibrium moisture content $(\mathrm{kg}$ water $/ \mathrm{kg} \mathrm{dm})$ and $M_{0}$ is the initial moisture content $(\mathrm{kg}$ water $/ \mathrm{kg} \mathrm{dm})$. The equilibrium moisture content $M_{e}$ was determined at the final stage of drying as an asymptotic value of the function fitted to the experimental points by using Table Curve 2D Windows v2.03 (Jandel Scientific Software, San Rafael, CA, USA). The drying curves were fitted to three commonly mentioned thin-layer drying models (Table 7). The best-fitted model that best described the drying processes was determined on the basis of the highest value of coefficient of determination $R^{2}$ and lowest root mean square error (RMSE).

Table 7. Mathematical models applied to drying curves of C. alata.

\begin{tabular}{cc} 
Model Name & Model Equation \\
\cline { 2 - 3 } Lewis & $M R=\exp (-k \cdot \mathrm{t})$ \\
Modified Page & $M R=a \cdot \exp \left(-k \cdot t^{n}\right)$ \\
Henderson and Pabis & $M R=a \cdot \exp (-k \cdot t)$ \\
\cline { 2 - 3 }$M R-$ moisture ratio; $a$-coefficient of the equation; $k$-drying constant $\left(\min ^{-1}\right) ; n$-exponent; $t$ - time (min).
\end{tabular}

\subsection{Water Activity Analysis}

The water activity of $C$. alata leaves was determined using a water activity meter (Aqualab 4TE, Pullman, WA, USA) and analysed at an average temperature of $24.9 \pm 0.05^{\circ} \mathrm{C}$.

\subsection{Determination of Energy Consumption}

\subsubsection{Energy Consumption}

The energy consumptions during the processes of $C D\left(E_{C}\right)$ and VMD $\left(E_{V M}\right)$ were calculated on the basis of Equations (3) and (4) [18].

$$
E_{C}=\left(\frac{N_{f}}{6}+N_{h}\right) \times t
$$


where $N_{f}(\mathrm{~kW})$ is the power consumption of the fan supplying air to the six pipes that were fixed with electric heaters requiring a power consumption of $N_{h} \cdot(\mathrm{kW})$, and $t$ is the drying duration (s).

$$
E_{V M}=\left(\frac{N_{M}}{\eta_{M}}+N_{V}+N_{e}\right) \times t
$$

where $N_{M}$ is the output power of the magnetrons $(\mathrm{kW}), \eta_{M}$ is the efficiency of the magnetrons, $N_{V}$ is the power consumption $(\mathrm{kW})$ of the vacuum pump, $N_{e}$ is the power consumption of the engine $(\mathrm{kW})$ that functions to rotate the container in the dryer and $t$ is the drying duration (s).

\subsubsection{Specific Energy Consumption}

The specific energies consumed by the process of CD, VMD and CPD-VMFD were determined on the basis of the ratio of energy consumed to the initial mass $m(\mathrm{~g})$ of the samples and the ratio of energy consumed to the mass of water $W(\mathrm{~g})$ removed from the samples.

The specific energy consumptions of $C D$, represented as $E_{C_{m}}\left(k J g^{-1} f w\right)$ and $E_{C_{W}}\left(k J g^{-1}\right.$ water $)$, were determined using Equations (5) and (6), respectively [18].

$$
\begin{aligned}
& E_{C_{m}}=\frac{E_{C}}{m} \\
& E_{C_{W}}=\frac{E_{C}}{W}
\end{aligned}
$$

Equations (7) and (8) show the specific energy consumptions of VMD, $E_{V M_{m}}\left(k J g^{-1} f w\right)$ and $E_{V M_{W}}\left(\mathrm{~kJ} \mathrm{~g}^{-1}\right.$ water $)$, respectively [18].

$$
\begin{aligned}
& E_{V M_{m}}=\frac{E_{V M}}{m} \\
& E_{V M_{m}}=\frac{E_{V M}}{W}
\end{aligned}
$$

The specific energy consumptions of CPD-VMFD, namely, $E_{C-V M_{m}}\left(k J g^{-1} f w\right)$ and $E_{C-V M_{W}}$ $\left(\mathrm{kJ} \mathrm{g}^{-1}\right.$ water), were calculated based on Equations (9) and (10), respectively [18]. Both equations are the ratios of the sum of energy $E_{C}$ and $E_{V M}$ to the mass of the initial sample $m$ (g) and the ratio of the sum of energy $E_{C}$ and $E_{V M}$ to the mass of water $(\mathrm{g})$ from $\operatorname{CPD}\left(W_{C}\right)$ and $\operatorname{VMFD}\left(W_{V M}\right)$ removed from the sample, respectively.

$$
\begin{aligned}
& E_{C-V M_{m}}=\frac{E_{C}+E_{V M}}{m} \\
& E_{C-V M_{m}}=\frac{E_{C}+E_{V M}}{W_{C} W_{V M}}
\end{aligned}
$$

\subsection{Colour Analysis}

The colour of fresh and dried ground leaf samples was analysed using a Minolta Chroma Meter CR-200 (Minolta Co. Ltd., Osaka, Japan). The data obtained were expressed using $L^{*}, a^{*}$ and $b^{*}$ coordinates. Colour measurements were repeated for five times. In every measurement, the fragmented fresh leaves were placed in different positions, and the ground and dried leaves were mixed in each reading.

\subsection{Extraction of Polyphenol Compounds}

The extraction of polyphenol compounds was carried out based on a method previously described [38]. Approximately $0.3 \mathrm{~g}$ of ground samples was measured in test tubes and mixed with $80 \%$ aqueous methanol $(0.7 \mathrm{~mL})$ and $1 \% \mathrm{HCl}$. The suspension was stirred and sonicated twice 
for $15 \mathrm{~min}$ and left to stand at $4{ }^{\circ} \mathrm{C}$ for $24 \mathrm{~h}$. The extract was centrifuged at 15,000 rpm (MPW-360R, Warsaw, Poland) for $10 \mathrm{~min}$, and the supernatants were collected thereafter.

\subsection{Antioxidant Activity Analysis}

\subsubsection{ABTS ${ }^{\bullet+}$ Radical-Scavenging Assay}

The ABTS radical-scavenging assay was performed to determine the free-radical-scavenging activity as described previously [39]. Firstly, ABTS was dissolved in water to obtain a solution of $7 \mathrm{mM}$ concentration. The resultant ABTS solution was mixed with $2.45 \mathrm{mM}$ potassium persulfate to produce ABTS radical cation $\left(\right.$ ABTS $^{\bullet+}$ ). This mixture was set aside in the dark at room temperature for $12-16 \mathrm{~h}$ prior to its use in the assay. Before the analysis, this solution was diluted with distilled water until an absorbance of $0.700 \pm 0.02$ at $734 \mathrm{~nm}$ is obtained. For the analysis, $300 \mu \mathrm{L}$ of diluted ABTS radical solution was initially mixed with $20 \mu \mathrm{L}$ of the extracted supernatant. The absorbance was measured using a UV-vis spectrophotometer (Shimadzu, UV-2401 PC, Kyoto, Japan) at $734 \mathrm{~nm}$ after $6 \mathrm{~min}$. Determinations of the absorbance value were performed in triplicate. The results were expressed relative to micromolar Trolox per $100 \mathrm{~g}$ of $\mathrm{dw}$ in terms of Trolox equivalent antioxidant capacity.

\subsubsection{FRAP Assay}

FRAP assay was performed as previously described by Benzie and Strain [40]. The FRAP reagent was formed by mixing acetate buffer $(300 \mu \mathrm{M}, \mathrm{pH} 3.6), 10 \mu \mathrm{M}$ TPTZ in $40 \mu \mathrm{M} \mathrm{HCl}$ and $20 \mu \mathrm{M}$ of $\mathrm{FeCl}_{3}$ at a ratio of 10:1:1 $(v / v / v)$. Thereafter, $300 \mu \mathrm{L}$ of the FRAP reagent was mixed with $10 \mu \mathrm{L}$ of the sample solution. Absorbance was measured using a UV-vis spectrophotometer (Shimadzu, UV-2401 PC, Kyoto, Japan) at $593 \mathrm{~nm}$ after $10 \mathrm{~min}$. A standard curve with different concentrations of Trolox was then plotted. Finally, determinations were performed in triplicates.

\subsection{Total Phenolic Content Analysis}

The total phenolic content was determined using the Folin-Ciocalteu method previously described by Gao et al. [41]. A sample extract of $0.1 \mathrm{~mL}$ was mixed with $0.2 \mathrm{~mL}$ of Folin-Ciocalteu reagent and $2 \mathrm{~mL}$ of water. This mixture was incubated at room temperature for $3 \mathrm{~min}$, subsequently added with $1 \mathrm{~mL}$ of $20 \%$ sodium carbonate and was incubated at room temperature for $1 \mathrm{~h}$. The absorbance was measured using an ultraviolet-visible light spectrophotometer (Shimadzu, UV-2401 PC, Kyoto, Japan) at a wavelength of $765 \mathrm{~nm}$. Quantification was performed on the basis of the gallic acid standard curve constructed, and results were expressed as gallic acid equivalence in milligrams per $100 \mathrm{~g}$ of $\mathrm{dw}$. All determinations were performed in triplicate.

\subsection{Analysis of Volatile Compounds}

\subsubsection{Headspace Solid-Phase Microextraction (HS-SPME)}

Volatiles were extracted using HS-SPME method, reported in a previous study with minor modifications [42]. Approximately $0.25 \mathrm{~g}$ of sample was inserted in glass vials with $2 \mu \mathrm{g}$ of $p$-methoxyphenol as the internal standard and subsequently placed in a laboratory water bath at $60{ }^{\circ} \mathrm{C}$ for $10 \mathrm{~min}$ for equilibration. SPME fibre, DVB/CAR/PDMS, 50/30 $\mu \mathrm{m}$, with $2 \mathrm{~cm}$ coating (Supelco, Bellefonte, PA, USA) was used for the extraction. The SPME fibre was inserted into the vial with sample that was kept in a water bath at $60^{\circ} \mathrm{C}$ for $30 \mathrm{~min}$. Next, the fibre was injected into the injection port of GC-MS at an injection temperature of $220^{\circ} \mathrm{C}$ for $3 \mathrm{~min}$ for analyte desorption.

\subsubsection{GC-MS Analysis of Volatile Compounds}

GC-MS analysis was conducted on Varian CP-3800/Saturn 2000 (Varian, Wallnut Creek, CA, USA) using a ZB-5MS capillary column $(30 \mathrm{~m} \times 0.25 \mathrm{~mm}$ inner diameter (i.d.) $\times 0.25 \mu \mathrm{m}$ film thickness). The GC oven temperature was programmed at $50{ }^{\circ} \mathrm{C}$, increased to $130{ }^{\circ} \mathrm{C}$ at a rate of $4{ }^{\circ} \mathrm{C} \mathrm{min}-1$, 
subsequently raised to $180{ }^{\circ} \mathrm{C}$ at $10{ }^{\circ} \mathrm{C} \mathrm{min}-1$ and finally to $280{ }^{\circ} \mathrm{C}$ at a rate of $2{ }^{\circ} \mathrm{C} \mathrm{min}-1$. Helium was used as a carrier gas at a flow rate of $1.0 \mathrm{~mL} \mathrm{~min}^{-1}$. The samples were injected at a 1:10 split mode. Mass spectra were obtained in an electronic ionisation (EI) mode of $70 \mathrm{eV}$ with a scan range of $\mathrm{m} / \mathrm{z}$ 35-550. Identification of all volatile compounds was based on comparing the compound mass spectra obtained experimentally, with the mass spectra available in the NIST14 database. The experimentally determined retention index (RI) by Kovats was also compared with the RI in NIST WebBook and literature data [43]. The quantification analysis of identified volatile compounds was calculated by comparing the peak area of compounds with the peak area of the internal standard ( $p$-methoxyphenol) with a concentration of $1 \mathrm{mg} / \mathrm{mL}$.

\subsection{Phytosterol and Fatty Acid Analysis}

\subsubsection{Lipid Extraction}

The lipid fraction was extracted on the basis of a method described in a previous study with minimal modifications [44]. Ground leaves were extracted using a 2:1 chloroform-methanol $(v / v)$ for $24 \mathrm{~h}$ and filtered thereafter. A vacuum rotary evaporator was used to remove the extraction solvent from the filtrate at $65^{\circ} \mathrm{C}$. The resultant crude lipids were saponified using $10 \mathrm{~mL} 0.5 \mathrm{M} \mathrm{KOH} / \mathrm{MeOH}$ at $80{ }^{\circ} \mathrm{C}$ for $10 \mathrm{~min}$, boiled with reflux for $10 \mathrm{~min}$ and was cooled to $12{ }^{\circ} \mathrm{C}$. The sample was placed in a separation funnel and added with $10 \mathrm{~mL}$ of hexane and $10 \mathrm{~mL}$ of water, and the mixture was mixed vigorously. Fatty acid fraction that was partitioned to the polar phase was segregated from the phytosterol fraction.

\subsubsection{GC-MS Analysis of Phytosterols}

Phytosterol portion that was obtained in Section 3.9.1 was dried with $\mathrm{MgSO}_{4}$, and the extraction solvent was evaporated using a vacuum rotary evaporator. The resultant residue was added with $0.2 \mathrm{~mL}$ of pyradine and $0.2 \mathrm{~mL}$ of BSTFA as a silylation agent. Approximately $1 \mathrm{mg}$ of cholesterol was added as the internal standard. This mixture was placed in an incubator orbital shaker at $110 \mathrm{rpm}$ and heated at $60{ }^{\circ} \mathrm{C}$ for $45 \mathrm{~min}$. Thereafter, this mixture was transferred to small tubes for GC-MS analysis. Identification of phytosterols was based on comparing the experimentally obtained mass spectra with the mass spectra available in literature and by comparing the relative retention times of the standards. The concentrations of identified phytosterols were obtained by comparing the peak area of each compound to that of the internal standard cholesterol with a concentration of $1 \mathrm{mg} / \mathrm{mL}$.

\subsubsection{GC-MS Analysis of Fatty Acids}

The fatty acid portion obtained in Section 3.9.1 was acidified with $1 \mathrm{M} \mathrm{HCl}$ and was extracted with $10 \mathrm{~mL}$ of hexane. The organic portion was segregated, whereas the extraction solvent was removed with a vacuum rotary evaporator. Methylation was performed by adding $4 \mathrm{~mL}$ of $14 \% \mathrm{BF}_{3} / \mathrm{MeOH}(v / v)$ at $80^{\circ} \mathrm{C}$ for $10 \mathrm{~min}$. The produced fatty acid methyl ester (FAME) was subsequently extracted with $2.5 \mathrm{~mL}$ of hexane, dried using $\mathrm{MgSO}_{4}$ and finally filtered with a cotton plug and silicate powder. The FAME profile was analysed using a GC-MS equipment (GCMS-QP 2020, Shimadzu, Kyoto, Japan). Separation was performed using a Zebron ZB-WAX capillary column $(30 \mathrm{~m} \times 0.25 \mathrm{~mm}$ i.d. $\times 0.25 \mu \mathrm{m}$ film thickness; Phenomenex, Torrance, CA, USA). The scanning was conducted at a mass range of $50-400 \mathrm{~m} / \mathrm{z}$ at an EI of $70 \mathrm{eV}$ and at a $5 \mathrm{scan} \mathrm{s}^{-1}$ mode. The carrier gas used was helium with a flow rate of $1.0 \mathrm{~mL} \mathrm{~min}^{-1}$ at a split ratio of 1:10. The temperature gradient programmes used were as follows: (a) $45^{\circ} \mathrm{C}$ for $3 \mathrm{~min}$, (b) $45^{\circ} \mathrm{C}$ to $220^{\circ} \mathrm{C}$ at a rate of $5^{\circ} \mathrm{C} \mathrm{min}-1$ and (c) $220{ }^{\circ} \mathrm{C}-250{ }^{\circ} \mathrm{C}$ at a rate of $10{ }^{\circ} \mathrm{C} \mathrm{min}-1$ and finally maintained at $250^{\circ} \mathrm{C}$ for $2 \mathrm{~min}$. The injector was held at a temperature of $260^{\circ} \mathrm{C}$.

\subsection{Statistical Analysis}

One-way analysis of variance (ANOVA) was performed using SPSS version 20 (IBM, Tulsa, OK, USA). The results were presented as means \pm standard deviation. Significant differences $(p \leq 0.05)$ 
between the mean values were evaluated with Tukey's test. Mathematical modelling was performed using Table Curve 2D Windows v2.03 (Jandel Scientific Software, USA). The RMSE and coefficient of determination $R^{2}$ were determined to know the goodness of fit of the mathematical models.

\section{Conclusions}

The drying kinetics of $C$. alata leaves dehydrated using CD, VMD and CPD-VMFD was best described by the exponential model (modified Page model). The antioxidant activity, TPC and total volatile concentration did not improve with the use of advanced drying methods (VMD and CPD-VMFD), as $\mathrm{CD}$ at $40{ }^{\circ} \mathrm{C}$ achieved the highest antioxidant activity, TPC and total volatile concentration. However, CPD-VMFD is effective in ensuring a high phytosterol concentration than $\mathrm{CD}$ at $50^{\circ} \mathrm{C}$. Drying of $\mathrm{C}$. alata leaves with VMD required the least energy than conventional CD and CPD-VMFD. However, CPD-VMFD is more efficient in energy saving because this combined drying method reduced the final energy consumption by $32.82 \%(\mathrm{~kJ} / \mathrm{g}$ fresh weight) and $26.12 \%(\mathrm{~kJ} / \mathrm{g}$ water) compared with $\mathrm{CD}$ at $50{ }^{\circ} \mathrm{C}$. FD produced dried C. alata with best the colour properties whilst CD at $60{ }^{\circ} \mathrm{C}$ produced sample with lowest $\mathrm{a}_{\mathrm{w}}$. Based on the results of this study, the final recommendation of a suitable drying method to dehydrate $C$. alata leaves is $\mathrm{CD}$ at $40^{\circ} \mathrm{C}$, considering the antioxidant activity, TPC and total volatiles yield.

Author Contributions: L.Y.W.C., B.L.C., C.H.C. and A.F. designed the experiment. L.Y.W.C., A.F., A.S., A.W. and K.L. performed the experiments. L.Y.W.C. (supported by B.L.C., A.F. and C.H.C.) wrote the manuscript.

Funding: The authors would like to acknowledge Taylor's University Lakeside for providing financial support under Taylor's Research Grant Schemes (TRGS/MFS/1/2017/SOE/008) and The Polish Ministry of Science and Higher Education "Strategy of Excellence-University of Research" Project (0019/SDU/2018/18).

Conflicts of Interest: The authors declare no conflicts of interest.

\section{References}

1. Sagnia, B.; Fedeli, D.; Casetti, R.; Montesano, C.; Falcioni, G.; Colizzi, V. Antioxidant and anti-inflammatory activities of extracts from Cassia alata, Eleusine indica, Eremomastax speciosa, Carica papaya and Polyscias fulva medicinal plants collected in Cameroon. Plos ONE 2014, 9, e103999. [CrossRef] [PubMed]

2. Somchit, M.N.; Reezal, I.; Elysha Nur, I.; Mutalib, A.R. In vitro antimicrobial activity of ethanol and water extracts of Cassia alata. J. Ethnopharmacol. 2003, 84, 1-4. [CrossRef]

3. Chatterjee, S. Cassia alata-An useful antimicrobial agent. Med. Aromat. Plants 2013, 2, e143. [CrossRef]

4. Ross, I.A. Cassia alata L. In Medicinal Plants of the World; Springer Science \& Business Media: New York, NY, USA, 2003; Volume 1, pp. 165-174.

5. Hazni, H.; Ahmad, N.; Hitotsuyanagi, Y.; Takeya, K.; Choo, C.Y. Phytochemical constituents from Cassia alata with inhibition against methicillin-resistant Staphylococcus aureus (MRSA). Planta Med. 2008, 74, 1802-1805. [CrossRef] [PubMed]

6. Chatterjee, S. Study of antioxidant activity and immune stimulating potency of the ethnomedicinal plant, Cassia alata (L.) Roxb. Med. Aromat. Plants 2013, 2, 2-7. [CrossRef]

7. Gupta, D.; Singh, J. Flavonoid glycosides from Cassia alata. Phytochemistry 1991, 30, 2761-2763. [CrossRef]

8. Okpuzor, J.; Ogbunugafo, H.; Kareem, G.K.; Igwo-Ezikp, M.N. In vitro investigation of antioxidant phenolic compounds in extracts of Senna alata. Res. J. Phytochem. 2010, 3, 68-76. [CrossRef]

9. Chan, J.W.R.; Chong, C.H.; Ng, D.K.S. Process synthesis and design for extraction of bioactive compounds from Strobilanthes crispus. J. Eng. Sci. Technol. 2015, 113-137.

10. Sarker, S.D.; Latif, Z.; Gray, A.I. Natural product isolation. In Natural Products Isolation, 2nd ed.; Humana Press: New Jersey, NJ, USA, 2005; pp. 1-25.

11. Wray, D.; Ramaswamy, H.S. Novel concepts in microwave drying of foods. Dry. Technol. 2015, 33, 769-783. [CrossRef]

12. Chua, K.J.; Chou, S.K. Recent advances in hybrid drying technologies. In Emerging Technologies for Food Processing, 2nd ed.; Sun, D.W., Ed.; Academic Press: London, UK, 2014; pp. 447-457.

13. Feng, H.; Yin, Y.; Tang, J. Microwave drying of food and agricultural materials: Basics and heat and mass transfer modeling. Food Eng. Rev. 2012, 4, 89-106. [CrossRef] 
14. Michalska, A.; Wojdyło, A.; Lech, K.; Łysiak, G.P.; Figiel, A. Physicochemical properties of whole fruit plum powders obtained using different drying technologies. Food Chem. 2016, 207, 223-232. [CrossRef]

15. Calín-Sánchez, Á.; Figiel, A.; Lech, K.; Szumny, A.; Carbonell-Barrachina, Á. Effects of drying methods on the composition of thyme ( Thymus vulgaris L.) essential oil. Int. J. 2013, 31, 224-235.

16. Figiel, A. Drying kinetics and quality of beetroots dehydrated by combination of convective and vacuum-microwave methods. J. Food Eng. 2010, 98, 461-470. [CrossRef]

17. Hu, Q.-g.; Zhang, M.; Mujumdar, A.S.; Xiao, G.-n.; Jin-Cai, S. Drying of edamames by hot air and vacuum microwave combination. J. Food Eng. 2006, 77, 977-982. [CrossRef]

18. Calín-Sánchez, Á.; Figiel, A.; Wojdyło, A.; Szarycz, M.; Carbonell-Barrachina, Á.A. Drying of garlic slices using convective pre-drying and vacuum-microwave finishing drying: Kinetics, energy consumption, and quality studies. Food Bioprocess Technol. 2014, 7, 398-408. [CrossRef]

19. Mathlouthi, M. Water content, water activity, water structure and the stability of foodstuffs. Food Control 2001, 12, 409-417. [CrossRef]

20. MacDougall, D.B. Colour in Food. Improving quality. Colour Food 2002, 388.

21. Wojdyło, A.; Figiel, A.; Oszmiański, J. Effect of drying methods with the application of vacuum microwaves on the bioactive compounds, color, and antioxidant activity of strawberry fruits. J. Agric. Food Chem. 2009, 57, 1337-1343. [CrossRef]

22. Manzocco, L.; Calligaris, S.; Mastrocola, D.; Nicoli, M.C.; Lerici, C.R. Review of non-enzymatic browning and antioxidant capacity in processed foods. Trends Food Sci. Technol. 2000, 11, 340-346. [CrossRef]

23. Hossain, M.B.; Barry-Ryan, C.; Martin-Diana, A.B.; Brunton, N.P. Effect of drying method on the antioxidant capacity of six Lamiaceae herbs. Food Chem. 2010, 123, 85-91. [CrossRef]

24. Li, R.; Shang, H.; Wu, H.; Wang, M.; Duan, M.; Yang, J. Thermal inactivation kinetics and effects of drying methods on the phenolic profile and antioxidant activities of chicory (Cichorium intybus L.) leaves. Sci. Rep. 2018, 8. [CrossRef]

25. Jaloszynski, K.; Figiel, A.; Wojdylo, A. Drying kinetics and antioxidant activity of oregano. Acta Agrophysica 2009, 11, 81-90.

26. Sun, Y.; Shen, Y.; Liu, D.; Ye, X. Effects of drying methods on phytochemical compounds and antioxidant activity of physiologically dropped un-matured citrus fruits. Lwt-Food Sci. Technol. 2015, 60, 1269-1275. [CrossRef]

27. Gonzalez-Burgos, E.; Gomez-Serranillos, M.P. Terpene compounds in nature: A review of their potential antioxidant activity. Curr. Med. Chem. 2012, 19, 5319-5341. [CrossRef] [PubMed]

28. Mao, S.; Wang, K.; Lei, Y.; Yao, S.; Lu, B.; Huang, W. Antioxidant synergistic effects of Osmanthus fragrans flowers with green tea and their major contributed antioxidant compounds. Sci. Rep. 2017, 7, 1-10. [CrossRef] [PubMed]

29. Hugo, P.C.; Gil-Chávez, J.; Sotelo-Mundo, R.R.; Namiesnik, J.; Gorinstein, S.; González-Aguilar, G.A. Antioxidant interactions between major phenolic compounds found in "Ataulfo" mango pulp: Chlorogenic, gallic, protocatechuic and vanillic acids. Molecules 2012, 17, 12657-12664.

30. Kowalczyk, D.; Świeca, M.; Cichocka, J.; Gawlik-Dziki, U. The phenolic content and antioxidant activity of the aqueous and hydroalcoholic extracts of hops and their pellets. J. Inst. Brew. 2013, 119, 103-110. [CrossRef]

31. Choe, E.; Min, D.B. Mechanisms of antioxidants in the oxidation of foods. Compr. Rev. Food Sci. Food Saf. 2009, 8, 345-358. [CrossRef]

32. Calín-Sánchez, Á.; Szumny, A.; Figiel, A.; Jałoszyński, K.; Adamski, M.; Carbonell-Barrachina, Á.A. Effects of vacuum level and microwave power on rosemary volatile composition during vacuum-microwave drying. J. Food Eng. 2011, 103, 219-227. [CrossRef]

33. Soupas, L.; Juntunen, L.; Lampi, A.M.; Piironen, V. Effects of sterol structure, temperature, and lipid medium on phytosterol oxidation. J. Agric. Food Chem. 2004, 52, 6485-6491. [CrossRef]

34. Rudzińska, M.; Przybylski, R.; Wąsowicz, E. Products formed during thermo-oxidative degradation of phytosterols. J. Am. Oil Chem. Soc. 2009, 86, 651-662. [CrossRef]

35. Shin, H.-Y.; Lim, S.-M.; Bae, S.-Y.; Oh, S.C. Thermal decomposition and stability of fatty acid methyl esters in supercritical methanol. J. Anal. Appl. Pyrolysis 2011, 92, 332-338. [CrossRef]

36. Charuwat, P.; Boardman, G.; Bott, C.; Novak, J.T. Thermal degradation of long chain fatty acids. Water Environ. Res. 2018, 90, 278-287. [CrossRef] 
37. Bourourou, M.; Duncan, M.W.; Lipsky, R.H.; Gorelick, P.B.; Marini, A.M.; Blondeau, N. Alpha-linolenic acid: An omega-3 fatty acid with neuroprotective properties-Ready for use in the stroke clinic? Biomed. Res. Int. 2015, 2015, 1-8.

38. Chua, L.Y.W.; Chua, B.L.; Figiel, A.; Chong, C.H.; Wojdyło, A.; Szumny, A.; Choong, T.S.Y. Antioxidant activity, and volatile and phytosterol contents of Strobilanthes crispus dehydrated using conventional and vacuum microwave drying methods. Molecules 2019, 24, 1397. [CrossRef]

39. Re, R.; Pellegrini, N.; Proteggente, A.; Pannala, A.; Yang, M.; Rice-Evans, C. Antioxidant activity applying an improved ABTS radical cation decolorization assay. Free Rad. Biol. Med. 1999, 26, 1231-1237. [CrossRef]

40. Benzie, I.F.F.; Strain, J.J. The ferric reducing ability of plasma (FRAP) as a measure of "antioxidant power": The FRAP assay. Anal. Biochem. 1996, 239, 70-76. [CrossRef]

41. Gao, X.; Ohlander, M.; Jeppsson, N.; Björk, L.; Trajkovski, V. Changes in antioxidant effects and their relationship to phytonutrients in fruits of sea buckthorn (Hippophae rhamnoides L.) during maturation. J. Agric. Food Chem. 2000, 48, 1485-1490. [CrossRef]

42. Politowicz, J.; Lech, K.; Sánchez-Rodríguez, L.; Szumny, A.; Carbonell-Barrachina, Á.A. Volatile composition and sensory profile of Cantharellus cibarius Fr. as affected by drying method. J. Sci. Food Agric. 2017, 97, 5223-5232. [CrossRef]

43. Adams, R.P. Identification of essential oil components by gas chromatography/mass spectrometry. Allured Publ. Corp. Carol Stream 2007, 1-804.

44. Folch, J.; Lees, M.; Stanley, G.H.S. A simple method for the isolation and purification of total lipids from animal animal tissues. J. Biol. Chem. 1957, 226, 497-509. [PubMed]

Sample Availability: Samples of the compounds are not available from the authors.

(C) 2019 by the authors. Licensee MDPI, Basel, Switzerland. This article is an open access article distributed under the terms and conditions of the Creative Commons Attribution (CC BY) license (http://creativecommons.org/licenses/by/4.0/). 